\title{
Communicating for Aquatic Conservation in Cambodia and Beyond: Lessons Learned from In-Person and Media-Based Environmental Education and Outreach Strategies
}

\author{
Erin K. Loury ${ }^{1, *(\mathbb{D}}$, Jackman C. Eschenroeder ${ }^{1}$, Lykheang Seat ${ }^{2}$, Seila Chea ${ }^{3}{ }^{\oplus}$, Chheana Chhut ${ }^{3}$, \\ Suthep Kritsanavarin ${ }^{3}$, Stefan Lovgren ${ }^{3}$, Elizabeth G. Ramsay ${ }^{1}$, Dee Thao ${ }^{4}$ and Zeb S. Hogan ${ }^{5}$ \\ 1 FISHBIO, 519 Seabright Ave, Suite 208, Santa Cruz, CA 95062, USA; jackeschenroeder@fishbio.com (J.C.E.); \\ elizabethramsay@fishbio.com (E.G.R.) \\ 2 Young Eco Ambassadors, \#21, Street 5A, Russey Keo Commune, Russey Keo District, \\ Phnom Penh 120703, Cambodia; kheang.yea@gmail.com \\ 3 Wonders of the Mekong Project, \#186, Preah Norodom Blvd., P.O. Box 582, Phnom Penh 12000, Cambodia; \\ seilacsloct@gmail.com (S.C.); chheana.lotus@gmail.com (C.C.); skritsana@gmail.com (S.K.); \\ stefan.1.lovgren@gmail.com (S.L.) \\ 4 FISHBIO, 180 East 4th Street, Suite 160, Chico, CA 95928, USA; deethao@fishbio.com \\ 5 Department of Biology and Global Water Center, University of Nevada, Reno, NV 89557, USA; \\ zhogan@unr.edu \\ check for \\ * Correspondence: erinloury@fishbio.com
} updates

Citation: Loury, E.K.; Eschenroeder, J.C.; Seat, L.; Chea, S.; Chhut, C.; Kritsanavarin, S.; Lovgren, S.; Ramsay, E.G.; Thao, D.; Hogan, Z.S. Communicating for Aquatic Conservation in Cambodia and Beyond: Lessons Learned from In-Person and Media-Based Environmental Education and Outreach Strategies. Water 2021, 13, 1853. https://doi.org/10.3390/ w13131853

Academic Editor: Nisikawa Usio

Received: 1 May 2021

Accepted: 21 June 2021

Published: 2 July 2021

Publisher's Note: MDPI stays neutral with regard to jurisdictional claims in published maps and institutional affiliations.

Copyright: (c) 2021 by the authors. Licensee MDPI, Basel, Switzerland. This article is an open access article distributed under the terms and conditions of the Creative Commons Attribution (CC BY) license (https:// creativecommons.org/licenses/by/ $4.0 /)$.

\begin{abstract}
Communication and outreach efforts are essential for raising awareness about conservation issues among the general public. This paper reviews three in-person approaches (environmental education, outreach events, and field trips), as well as four types of media (print products, news media, visual media, and social media) for communicating about environmental topics, with a focus on highlighting conservation issues in Cambodia. Strengths and weaknesses are considered for each communication tool, along with lessons from a case study example of the Wonders of the Mekong, an interdisciplinary project based in Cambodia that aims to study, protect, and raise awareness about the Mekong River system. We also describe a cross-cutting initiative to share inspiring stories of local conservation practitioners that incorporates both in-person and media-based approaches. In terms of required resources and effort, there is an inherent tradeoff between the depth of in-person engagement and overall reach. While media-based approaches are valuable for reaching large numbers of people with a moderate amount of effort, in-person approaches may create a deeper connection and longer-term impact on an individual level. Ultimately, a diverse communication strategy that utilizes multiple tools to reach different audiences will be most effective. The interdisciplinary Wonders of the Mekong project has successfully communicated the values of the Mekong ecosystem to a broad audience in Cambodia using a variety of strategies, and further evaluation could help illuminate whether and how these communication approaches are shifting attitudes or promoting conservation behaviors.
\end{abstract}

Keywords: Lower Mekong Basin; engagement; social media; freshwater

\section{Introduction}

Conservation of natural resources typically requires behavior change, which, in turn, requires a level of awareness and concern [1]. Communication to raise awareness and inspire action, therefore, plays an important role in driving change [2], and strategies such as education, outreach, and engagement are frequently incorporated into conservation efforts [3-5]. Numerous organizations and programs are currently working to conserve the ecologically diverse natural resources of the Lower Mekong Basin, which have great economic and cultural importance [6,7]. These resources face many complex threats, including overexploitation, development, and climate change, which will take political will and 
collective action to address [8-12]. At the same time, the importance and uniqueness of the Mekong's biodiversity, natural resources, and ecosystem services are widely undervalued and underappreciated in the region [13-16]. Strategic communication actions are, therefore, needed to raise the profile of the Mekong River's value to ensure the river's resources can be sustained into the future.

The Mekong River's natural resources are critical to the people of Cambodia, yet their conservation value may be underprioritized. Supported by the Mekong River ecosystem and the Tonle Sap Lake, Cambodia has some of the highest rates of freshwater fish production and per capita rates of fish consumption in the world [17,18]. In this resourcedependent country, nature is often viewed through the lens of "natural resources", in which biodiversity is valued primarily as an exploitable commodity. As with other tropical countries, Cambodia faces competing pressures to simultaneously preserve rich biodiversity while also advancing social and economic development [19]. The negative consequences for biodiversity and ecosystem function in this tradeoff are apparent in the unsustainable exploitation of natural resources, reflected in declining fish catches [20], declining wildlife diversity [21,22], and increasing deforestation rates [23]. In the push for development, Cambodians may lose some of their rich natural heritage without full awareness of its extent and ecological value, which underscores the importance of environmental education and outreach.

Environmental education efforts in Cambodia have been largely informal (outside of a classroom setting) and have typically been adopted on a per-project basis at a local scale, such as in support of community forestry or community fishery initiatives [24,25]. Cambodia has a high literacy rate of $81 \%$ [26], but $76 \%$ of the population lives in rural areas [27], which can present logistical challenges to delivering educational programs. However, Cambodians have become extensively connected digitally: as of 2019, there were 8.8 million registered Facebook accounts in Cambodia, which is roughly eight accounts for every ten of the 10.58 million people between the ages of 15 and 64 in a country of 16.48 million $[28,29]$. This presents a sizeable opportunity for reaching large numbers of people through social media and other digital forms of communication.

While communication can take multiple forms, the various approaches discussed in this review require common essential elements, such as identifying the intended audience and choosing the right tools to engage with that audience [30-33]. Defining the scope of an audience (e.g., national vs. international) will influence the choice of language for communication, as well as the platforms used [30,34]. Successful communication campaigns also rely on crafting compelling messages that resonate with the target audience [30,34,35]. The same message can be adapted to different media or communication tools to broaden its reach.

Our discussion of communication for conservation incorporates tools and strategies from the fields of environmental education and science communication, recognizing that, while these fields are often defined differently, they have great overlap in practice $[32,33,36]$. While others differentiate strategies of communication, education, outreach, and engagement based on purpose, audience, setting, or level of audience participation [32,37-39], our focus is on discussing the communication tools themselves from the perspective of a conservation organization, with the understanding that a single tool can be used for multiple purposes or audiences. We have grouped tools based on whether audience engagement typically occurs (1) in person or (2) remotely. While the COVID-19 pandemic has demonstrated how many of the in-person tools can be adapted to remote or virtual applications, here, we predominantly focus on their traditional in-person uses.

This review compares the benefits and challenges of seven types of communication tools to aid conservation, which can generally be classified as (1) in-person education and outreach (including school visits, public events, and immersion experiences); and (2) media-based outreach (including print products, traditional news media, video, and social media). We also explore a cross-cutting approach that combines in-person and media-based elements for outreach and engagement. For each strategy, we provide a 
review of available published literature around the role of this strategy in communication for conservation, and compare strengths and weaknesses of the various strategies, such as the level of effort required, accessibility, and relative reach (Table 1). We also highlight examples from a case study based on Wonders of the Mekong (WOM), a multidisciplinary collaborative project focused on Cambodia and funded by the U.S. Agency for International Development (USAID).

Table 1. Comparison of attributes of conservation communication tools. Low reach is considered dozens to hundreds of people, medium reach is hundreds to thousands of people, and large reach is thousands to hundreds of thousands of people.

\begin{tabular}{|c|c|c|c|c|c|}
\hline Strategy & $\begin{array}{l}\text { Typical Audience } \\
\text { Engagement }\end{array}$ & $\begin{array}{l}\text { Level of } \\
\text { Resources and } \\
\text { Effort Required } \\
\text { to Develop }\end{array}$ & $\begin{array}{l}\text { Level of } \\
\text { Resources and } \\
\text { Effort Required } \\
\text { to Distribute }\end{array}$ & $\begin{array}{l}\text { Access to } \\
\text { Technology } \\
\text { Required? }\end{array}$ & $\begin{array}{c}\text { Relative Reach } \\
\text { of a Single } \\
\text { Effort }\end{array}$ \\
\hline $\begin{array}{l}\text { Environmental } \\
\text { Education }\end{array}$ & In Person & High & Medium & No & Medium \\
\hline Outreach Events & In Person & High & High & No & Medium \\
\hline Field Trips & In Person & High & High & No & Low \\
\hline Print Products & Remote $^{1}$ & High & Medium & No & Medium \\
\hline News Media Outlets & Remote & Medium & Low & Mostly Yes & Large \\
\hline Visual Media & Remote $^{1}$ & High & Medium & Mostly Yes & Large \\
\hline Social Media & Remote & Medium & Low & Yes & Large \\
\hline
\end{tabular}

${ }^{1}$ Often incorporated into in-person activities as well.

The WOM project aims to maintain the ecological, cultural, and economic integrity of the vital Mekong River system through a three-pronged approach of (1) interdisciplinary research, (2) capacity building, and (3) education and outreach. This third component includes raising awareness about the value of the river's many extraordinary "wonders", such as diverse species, abundant fisheries, a unique and productive river system, and rich cultural heritage. The project also seeks to educate about threats to the Mekong's natural wonders, including overfishing, destructive fishing practices, deforestation, pollution, climate change, and hydropower construction. WOM has produced a variety of media and research outputs on these topics since 2017 [22,23,40-43] (see also https: / / www.facebook. com/MekongWonders, Accessed on: 28 June 2021). For each of the WOM case study examples, we describe successes, challenges, and key lessons learned about applying a given communication tool in Cambodia to support conservation outcomes. Many activities were implemented with the help of Young Eco Ambassador (YEA), a youth-led Cambodian organization and key WOM partner established to empower, inspire, and educate youth and society about sustainable ways of living.

\section{In-Person Communication Strategies}

\subsection{Environmental Education}

Educating youth may be viewed as a long-term investment in conservation, making young people a valuable audience for conservation outreach. Youth may be more receptive to conservation messages than older age groups [4], and can also serve as catalysts for raising environmental awareness among adults [44]. Environmental education for youth can be a formal process tied to in-classroom learning, and may involve the use of environmental literacy standards, such as those developed by the North American Association for Environmental Education [45]. These standards include a range of competencies or skills, such as identifying, investigating, and analyzing environmental issues, and incorporate both knowledge and attitudes [45]. Many countries have integrated these or similar standards into primary and secondary school curricula to cultivate environmental responsibility among future generations $[25,46,47]$.

Environmental education can also take an informal approach, in which visiting groups make outreach presentations or lead hands-on activities in a classroom setting [48]. Other informal education tools discussed in the following sections include events [49] and field 
trips to interpretive institutions or natural settings $[50,51]$. The integration of both formal and informal environmental education in primary schools has been shown to be an effective strategy for instilling a sense of purpose around environmental conservation in students worldwide [49,52-56].

In Cambodia, the official curriculum framework includes an objective on the value of science in the context of national economic development [57], but does not include specific learning goals related to environmental literacy or conservation. However, some environmental education efforts are underway at a national level. In 2019, the Cambodian Ministry of Environment and the Ministry of Education, Youth and Sports published a primary and secondary-level education guidebook on climate change, which covers climate change causes, impacts, and adaptations [58], and has been implemented in at least 10 schools selected for mainstreaming climate change in education. Organizations such as the Documentation Center of Cambodia (DC-Cam) provide examples of how classroom-based education initiatives can be scaled up to reach much larger audiences. The DC-Cam "Teachers' Guidebook" on the history of Democratic Kampuchea developed in collaboration with the Cambodian Ministry of Education [59] has been used to train 3000 teachers and has been distributed to at least 300,000 students, with plans for eventual distribution to all students in Cambodia.

Developing educational curricula and activities requires a high level of effort compared to other approaches (Table 1), and suitable language needs to be used for the intended grade level. Distribution requires training educators in the subject matter, which has been identified as a limiting factor for environmental education in Southeast Asia [25], but can be achieved with focused effort and resources. While a single educational event will likely have only a medium level of reach (i.e., dozens of students in a single or multiple classrooms), the material can reach hundreds of thousands of children across the country if environmental curricula can be integrated into national education standards. As few technological resources are necessary for environmental education presentations, such activities may be applied in rural or technology-limited settings. However, the COVID19 pandemic highlights the value of developing technology-based activities for remote learning when in-person activities are not possible.

\section{WOM Case Study}

WOM is currently developing an education guide for teachers specifically focused on the Mekong River ecosystem. This guide presents the abiotic and biotic elements of the Mekong River system as "wonders" of the Mekong, as well as human interactions with the river and needed actions to conserve these wonders. In terms of in-person activities, WOM project partner YEA has visited 16 schools, universities, and education centers since 2018 and reached approximately 1500 students at primary, high school, and university levels with environmental lessons. Primary school visits included games and a coloring book activity (discussed in a later section), while visits with older students included videos and presentations from conservation professionals, including the Mekong Conservation Heroes (discussed in a later section). These presentations covered various environmental topics, including freshwater fish research and conservation in Cambodia, the wetlands of Tonle Sap Lake, and preserving Cambodian birds through ecotourism.

Educational programs have introduced students to conservation topics, Cambodia's diverse landscapes, and threatened wildlife species. These school visits have also provided an effective opportunity to recruit students for continued engagement in environmental activities. For example, as a result of school presentations, approximately 50 students signed up to volunteer for an environmental outreach event organized by YEA. Challenges include scaling up the program to reach more students, which can be limited by the number and mobility of educators. With one exception of a visit to Battambang University, the visits all took place at schools in Phnom Penh, an urban center where YEA and WOM are headquartered. While there are benefits to providing environmental education to students 
in cities who might have less exposure to nature as part of their daily lives [49], a concerted effort is needed to reach Cambodia's mostly rural population.

\subsection{Outreach Events}

To maximize the effectiveness of public engagement, conservation practitioners need to reach a wide range of audiences, including those with little overt interest in the environment. One of the most important elements of effective communication is trust between the audience and the communicator. An effective way to build trust with new audiences, or those that are unfamiliar with the subject matter, is through face-to-face communication [60-64]. Therefore, many environmental organizations use in-person outreach events and activities as a way to celebrate, raise awareness, or generate pride for the environment [35]. These informal learning experiences can foster an understanding that conservation can be personally relevant, rewarding, and enjoyable [65]. Outreach events can be effective for reaching large numbers of people of all ages in urban settings and can also be held at a smaller scale at the community level. For example, the Wildlife Conservation Society has used shadow puppet theater to communicate a fable to rural communities in Cambodia about how harvesting wild bird eggs and hunting endangered birds would bring bad karma. This activity tapped into local religious and cultural beliefs to encourage conservation of the endangered Bengal florican (Houbaropsis bengalensis; Hong Chamnan, pers. comm.).

Planning and hosting outreach events can be resource-intensive in terms of time, cost, and materials, and their reach is limited to those who can access the venue. Attracting an audience is also a challenge; however, conservation groups can leverage each other's networks by organizing joint outreach events, or by taking part in festivals or other large, planned gatherings. Joining events that do not have an overt conservation or scientific focus can help reach new audiences who might not have actively sought out such information, and engage with them in a relaxed setting where people are typically open to novel experiences [65]. Coordinated events such as World Fish Migration Day can be used as part of a broader social movement to shift norms, such as promoting the importance of free-flowing rivers for fishes [35].

\section{WOM Case Study}

In June 2019, YEA hosted an outreach event as a culmination of an engagement campaign called the Mekong Generation, which drew more than 1000 participants from schools, conservation organizations, donors, and Cambodian ministries. The event included booth exhibits from local conservation organizations, and showcased awareness-raising materials developed by the Mekong Generation participants, such as storybooks, games, and artwork. This was followed by a conservation career panel discussion, and the event finale included two musical performances. YEA worked with the traditional Cambodian dance group Mascot Cambodia and Arts to tell the story of an Irrawaddy river dolphin (Orcaella brevirostris) inspired by a Cambodian folktale (Figure 1a). This partnership supports the revival of Cambodia's traditional artforms while also highlighting environmental issues faced by the endangered dolphins, such as the threat of entanglement in fishing gear. Using artistic approaches such as music and dance to introduce scientific or environmental concepts can produce memorable messages that resonate on an emotional level [66]. YEA also collaborated with the popular musical group SmallWorld SmallBand to write a song about the Mekong River, which drew enthusiasm from the young audience. Celebrity endorsements around conservation topics are a popular marketing strategy in Asia, although their effectiveness has yet to be empirically evaluated [67].

Other popular outreach events organized by WOM include an outreach festival in December 2019 that incorporated nature film screenings and hands-on exhibits from the Cambodian Nature Center, such as interactive touch-screen videos, microscopes, wildlife skulls, and games (Figure 1b). The event drew 500 participants, and 30 signed up to participate in a future event to celebrate World Fish Migration Day (WFMD). The WFMD 
event took place in October 2020, when WOM worked with the Cambodian Fisheries Administration to release more than 7000 fingerlings of captive-reared native fishes, including endangered species, into the Mekong River near Phnom Penh. The event engaged high-level representatives of government ministries and development partners, and many Cambodian media outlets and TV stations helped promote educational slogans developed by the project related to the importance of a healthy, connected Mekong River system. Inviting high-ranking government officials to participate in environmental events is a way to demonstrate support for environmental conservation in Cambodia [25], and the Director General of the Fisheries Administration noted that this kind of awareness-raising celebration will be added to the administration's strategic plan. Connecting event participants with YEA's ongoing activities has been an important strategy to sustain audience interest, engagement, and participation in conservation-oriented activities beyond a one-time event.

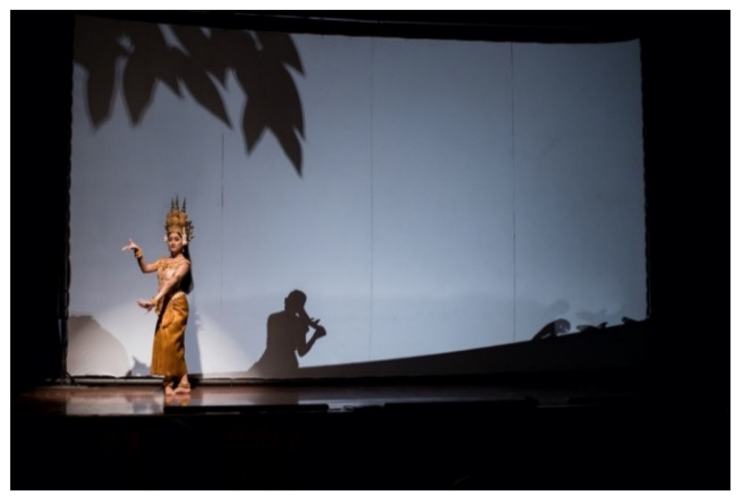

(a)

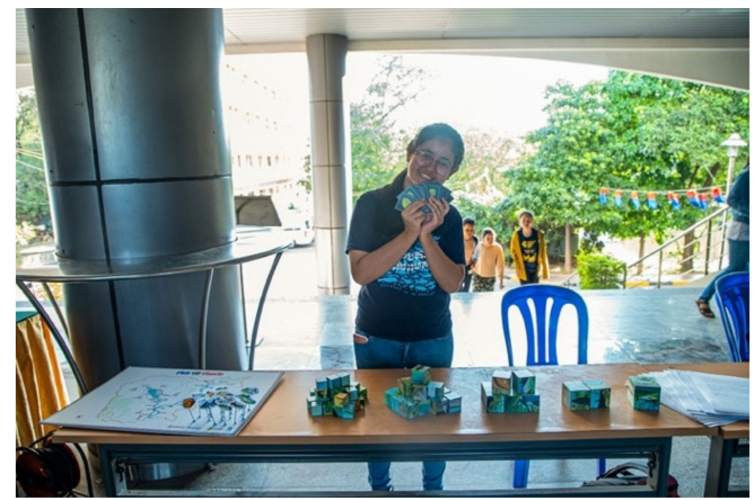

(b)

Figure 1. Conservation outreach festival in Phnom Penh: (a) Traditional shadow dance performance depicting a folk tale about a river dolphin; (b) a member of Young Eco Ambassador demonstrates an environmental game.

\subsection{Field Trips and Immersion Experiences}

Bringing students and adults into nature through field trips is an effective means of improving environmental knowledge and building a connection to natural environments e.g., [68-70]. Field trips have been shown to positively affect student learning and motivation [71], provide a visual space for students to understand complex environmental concepts [50], promote positive attitudes toward the site where the field trip took place [72], and create lasting impressions that persist into adulthood [73]. Field trips are also shown to instill pro-environmental attitudes, boost individual confidence in concepts, and encourage intrinsic motivation to help the environment [51]. Of particular importance, formative childhood experiences in nature are often cited by conservation leaders as a key motivating factor to pursue their career paths [74]. Bringing people into nature is vital for restoring a connection between people and freshwater ecosystems, and can counter the effects of urbanization [36]. Experiential learning focused on place-based engagement is also recognized as an important tool to overcome the human-nature disconnect that leads to many conservation challenges [75]. In addition, field trips provide an opportunity to educate national and international tourists as part of ecotourism ventures, which can help instill a conservation ethic in visitors [76]. The educational outcomes of ecotourism may be further improved by providing conservation education to local community members who are involved in the tourism activities [77].

Alternatively, the use of virtual field trips increases the accessibility of immersive experiences and may provide many of the same learning benefits [78]. Technologies such as satellite communication, webcams, and interactive websites allow students to directly communicate with scientists or other subject experts, collaborate with students in other schools, or conduct a virtual tour of an ecosystem or specific location. In the context of the 
recent COVID-19 pandemic, such virtual field trips are a way to engage students when in-person interactions must be limited, and best practices and guidelines, e.g., [79,80], can help educators tailor virtual field trips to specific learning goals and curricula [81]. Compared to other forms of outreach, in-person field trips have a relatively modest reach, as they are only available to engage small groups with the means to participate, and the number of visitors may need to be limited to preserve fragile natural places. In addition, field trips are relatively resource-intensive in terms of the time, effort, and cost to plan, coordinate logistics and transportation, and ensure the safety of participants. However, providing people with direct experiences in natural settings may help participants develop a deeper connection to nature more effectively than other forms of outreach.

\section{WOM Case Study}

In 2017, YEA founded a program called Der Prey ("Forest Trekking” in Khmer) to help urban Cambodians experience nature and learn how local people and conservationists work to protect the country's landscapes. The program's founders had previously worked with nongovernmental organizations that funded such trips to bring people to conservation sites. The Der Prey model makes the opportunity accessible to anyone with an interest and ability to cover their costs, which average about USD 100 per person. Since its founding, the group has taken more than 2000 Cambodian students, business owners, and corporate staff between the ages of 16 and 35 on more than 30 immersive nature experiences. These have included trips to the evergreen forests of the Cardamom Mountains, the wetlands of Tonle Sap Lake and the Mekong River, the dry forests of the Eastern Plains Landscape, and the central lowland forest in the Prey Lang Wildlife Sanctuary. The trips may involve tours or talks from community members to learn how local livelihoods depend on natural resources, such as fishing, harvesting plants, or gathering wild honey. Participants are introduced to topics such as the history of protected areas, law enforcement and conservation practices, local beliefs, and traditional knowledge about plants and wildlife. Other activities include nature walks, reflections, and discussions among participants about their connection to nature (Figure 2).
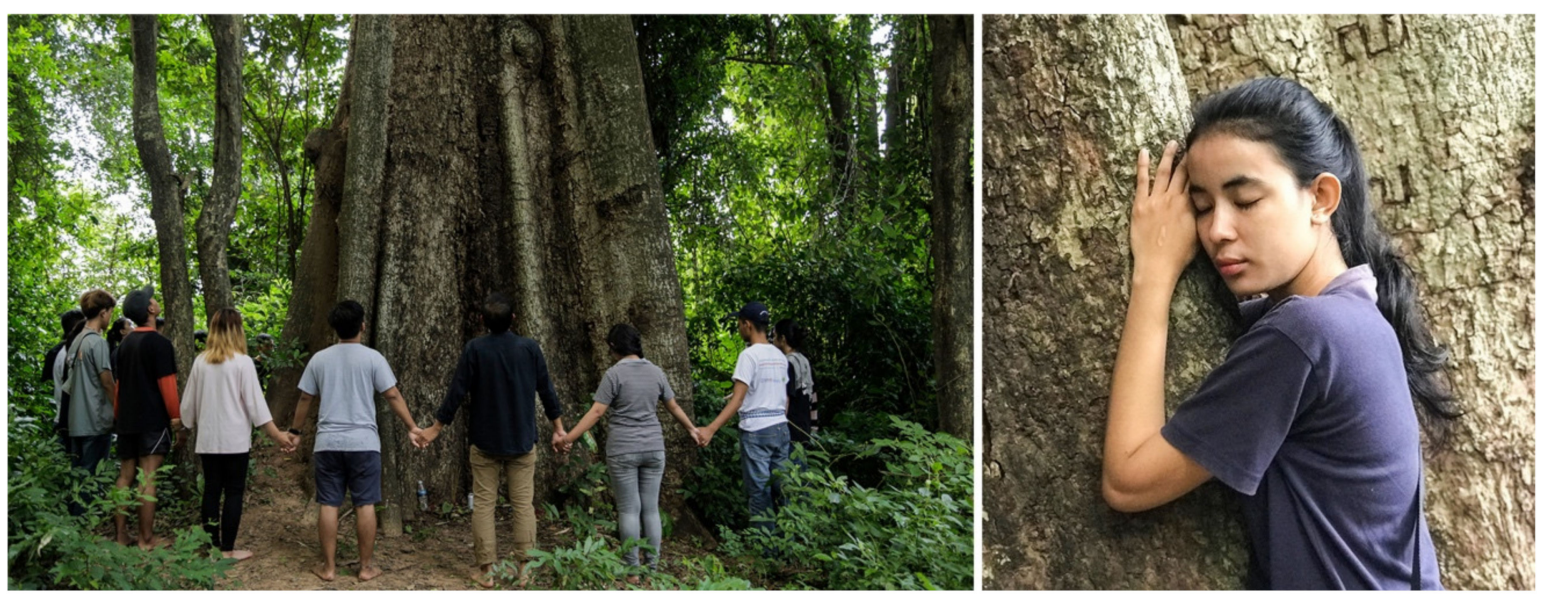

Figure 2. Photos of Cambodian youth visiting a forest as part of the Young Eco Ambassador Der Prey program.

For many participants, the trips with Der Prey were their first experiences trekking or visiting protected forests. The trips helped some overcome their fears about adventure travel, and roughly $80 \%$ of attendees have continued trekking after their first experience, either by joining subsequent Der Prey trips, or traveling on their own. Some participants were also inspired to make donations to the local communities they visited. One businessman who visited the Chroy Svay Community Fishery donated USD 250 to support the community in building more toilets. A group of visitors to Phnom Aural in the Cardamom Mountains collectively donated USD 150 to support community forestry patrolling, while 
a group of visitors to the Mekong River in Stung Treng donated USD 160 to help support a community affected by the construction of the Lower Sesan 2 Dam. To help sustain participant interest and engagement following the field trips, YEA created a campaign for young people to develop conservation projects and receive mentorship and technical support. Since 2015, more than 200 youth have participated in the program, and some turned their projects into career pathways, such as starting a business to create eco-friendly feminine hygiene products. In addition to motivating participants to become more active in environmental activities, the trips have generated about USD 30,000 of income for local communities through tourism services they provide, such as transportation, food, lodging, and tour guiding.

\section{Media-Based Communication Strategies}

\subsection{Print Products}

Despite the increasing use of the internet to disseminate information, traditional print materials such as brochures, posters, books, and games can be more effective for engaging with remote or rural audiences with limited access to technology. Print materials, especially posters, have frequently been used in Cambodia to visually communicate environmental concepts to rural populations with a low level of formal education or background knowledge [25]. Such products may also be incorporated as learning aids in formal educational activities or informal outreach events. Activities such as games have the potential to mobilize knowledge and conservation action by allowing children to model future adult conservation behaviors and by allowing adults to improve their skills in a low-risk setting [82]. Storybooks have also been used as a tool in Cambodia to introduce children to local endangered animals [25], and using subtle anthropomorphism in such stories can help children increase empathy and environmental knowledge [83].

Although they may require significant expertise to design and produce, and do not replace the need for in-person communication, printed materials can be a highly effective means of conveying information, promoting substantive dialogue, and demonstrating an organization's desire to engage with the public [84]. Once created, print materials can be distributed relatively easily and make environmental information accessible to those who may have limited or no access to technology or internet-based resources. Such materials may be incorporated as visual aids or engagement tools to promote dialogue during in-person events.

\section{WOM Case Study}

The WOM project has developed a variety of print outreach products, including books, posters, wall calendars, and playing cards, that feature Cambodia's diverse fish species. One of the most popular print products has been a coloring book called "Coloring Fish in our Country". The book includes color illustrations of 22 Mekong River fish species, accompanied by black and white outlines of the illustrations for coloring (Figure 3). The book contains basic biological information about each species in Khmer, such as its maximum size, habitats, and feeding habits. In addition to children, the coloring book also provides a means to engage adults, who have been observed reading about the fish species to their children.

Scientists from WOM have distributed coloring books in remote villages during field data collection as a way of integrating outreach and research activities. Nearly 6000 copies of the first edition of the coloring book were distributed, and another 2000 copies of a second edition featuring additional fish species have been printed for distribution. YEA and WOM staff have used the coloring books to hold several coloring contests in rural primary schools, which are used to raise awareness about protecting fish species and stopping the use of illegal electrofishing gear. During such events, some students learned for the first time about the giant fishes living in Cambodia that need protection.

Once the fish drawings were created for the coloring book, they could be readily adapted for other print materials such as playing cards, wall calendars, hanging artwork, 
and additional picture books, providing an opportunity to reach additional people. WOM printed and distributed a total of 1000 wall calendars in 2020 and 2021 to showcase a diversity of Mekong fish species. Members of YEA also wrote and illustrated a storybook about a boy named Kiri who is asked by an elder to protect the Prey Lang Forest of Cambodia. This story introduces different Cambodian wildlife species as heroes, such as the wild ox (Bos sauveli), giant ibis (Thaumatibis gigantea), Mekong river dolphin, giant stingray (Urogymnus polylepis), and giant barb (Catlocarpio siamensis), who work together to tackle deforestation, plastic waste, and other environmental threats. To date, 1000 copies of the story book have been produced and distributed.

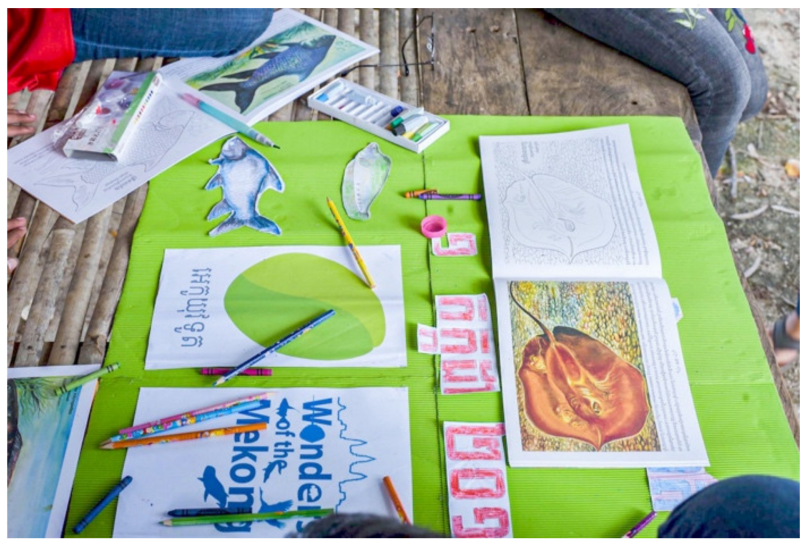

(a)

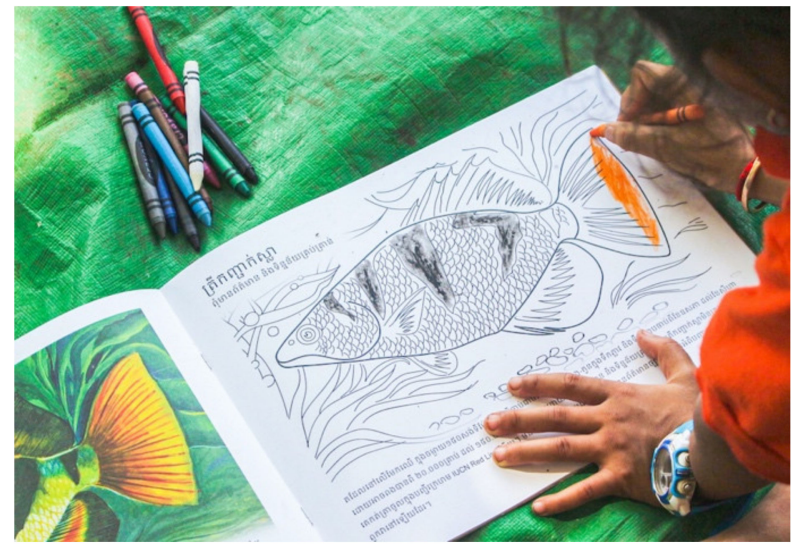

(b)

Figure 3. (a) Materials at a coloring event organized by Young Eco Ambassador; (b) a Cambodian child colors in the Wonders of the Mekong coloring book.

\subsection{News Media Outlets}

Perhaps one of the most effective ways for a project or organization to quickly expand its audience is by being featured on a news media outlet, particularly media with national or international reach. Although social media and new digital channels have transformed the media landscape in the last 15 years, traditional media outlets still claim considerable market share, even in the digital sphere. Recent conservation initiatives have demonstrated the value of leveraging print, online, and broadcast media outlets to distribute messaging and key information to audiences of hundreds of millions of people, e.g., Project Ocean [85]. Information on conservation initiatives distributed via news stories and other media pieces carries the added benefit of third-party credibility, and is generally perceived as more objective and unbiased than information distributed by the organization conducting the initiative [84]. The general public often gains awareness of environmental issues and conservation programs through news media [86], and traditional media sources are one way for conservation organizations to reach policy makers [35]. In Cambodia, government ministries have previously worked with national television and radio stations to broadcast segments related to environmental education, including quiz shows [25].

The effort required to report and craft a story deemed of publishable quality for a large media outlet is relatively high for the journalist writing the story, as in-person (or "on-the-ground") reporting is generally required for articles to be approved. On the other hand, a relatively low amount of effort is needed on the part of conservation organizations that develop working relationships with journalists. The organization may be called upon to provide the journalist access to interview subjects, background material, and project sites. Likewise, the level of resources and effort required for the distribution of stories is low, as established news organizations already have effective distribution channels and communication networks in place. Relative reach is very high, especially when working with nationally or globally recognized media outlets. 
Challenges and limitations to working with an independent news outlet include a lack of control over story framing or messaging. For this reason, it is critical to consider any potential negative angles on which a journalist may focus, and to provide specific responses to concerns that are likely to arise [84]. Conflicts of interest can also arise between a journalist's responsibility for objectivity, truth, and accuracy, and the desire of organizations or influential partners or donors to avoid highlighting negative aspects such as project failures or corruption. It can also be difficult for an organization to measure the reach or impact and evaluate the success of various messages that are communicated through an independent media outlet. However, a story is likely to be picked up and communicated by other conservation organizations if it is distributed by a news outlet, especially if those conservation groups feature in the story. Therefore, pitching environmental stories to a news organization is a worthwhile endeavor for conservation organizations, especially if the goal is to reach large audiences to broadly raise awareness and stimulate dialogue about key issues.

\section{WOM Case Study}

A goal of the WOM project is to communicate conservation messages about the Mekong region to Cambodian, regional, and international audiences. To achieve this goal, the WOM project has maintained relationships with several media outlets since 2017 to promote stories about Mekong issues, including National Geographic. As one of the most prominent media brands in the world, with an online audience that outweighs its print and television distribution, National Geographic claims to reach more than 450 million people across all media platforms. With 167 million followers (as of June 2021), it is the most followed noncelebrity brand on Instagram. WOM project leader Zeb Hogan (paper co-author) has a long-standing affiliation with the organization as a National Geographic Explorer and host of the National Geographic television show "Monster Fish", which helped forge the project's media relationship. Between March 2017 and August 2020, National Geographic published 17 articles focused on Mekong issues, wonders, and threats (Table 2), of which seven included an accompanying short video story. All but one of the stories were written by WOM project member Stefan Lovgren (paper co-author), who has been a contributor to National Geographic since 2003.

Based on traffic data from the National Geographic website, the most popular story was about the giant stingray (Table 2), which reflects the popularity of stories about largebodied animals [87]. The next three most viewed stories all relate to the crisis of low water levels in the Mekong River. National Geographic also shares stories on Facebook, where it has more than 48 million followers as of June 2021. The Mekong story that generated the most Facebook engagements was about the extinction risk of large freshwater species (Table 2), again reflecting the popularity of charismatic megafauna. The story's 4000 shares are more than four times higher than the next most shared story. The stories with the next highest engagement on Facebook included hopeful stories about increasing populations of other charismatic species, giant softshell turtles (Pelochelys cantorii) and Irrawaddy river dolphins. 
Table 2. Engagement metrics of recent National Geographic stories about Mekong River topics, ranked by number of website visitors.

\begin{tabular}{|c|c|c|c|c|c|c|c|}
\hline No. & Publication Date & Story Title & $\begin{array}{l}\text { Unique Visitors on } \\
\text { National } \\
\text { Geographic Website }\end{array}$ & $\begin{array}{c}\text { Facebook } \\
\text { Engagements } \\
\text { (Likes) }\end{array}$ & $\begin{array}{l}\text { Facebook } \\
\text { Comments }\end{array}$ & $\begin{array}{c}\text { Facebook } \\
\text { Shares }\end{array}$ & $\begin{array}{l}\text { Video } \\
\text { Story }\end{array}$ \\
\hline 1 & 24 December 2019 & This giant stingray could be the world's biggest freshwater fish & 153,762 & 3600 & 167 & 315 & No \\
\hline 2 & 31 July 2019 & Mekong River at its lowest in 100 years, threatening food supply & 50,274 & 1200 & 364 & 229 & No \\
\hline 3 & 17 August 2020 & Cambodia's biggest lake is running dry, taking forests and fish with it & 31,103 & 3200 & 71 & 304 & No \\
\hline 4 & 31 January 2020 & Southeast Asia's most critical river is entering unchartered waters & 31,010 & 3000 & 128 & 286 & No \\
\hline 6 & 8 August 2019 & Earth's largest freshwater creatures at risk of extinction & 30,303 & 9700 & 421 & 4000 & No \\
\hline 7 & 23 August 2018 & Southeast Asia may be building too many dams too fast & 26,339 & 1200 & 42 & 105 & No \\
\hline 8 & 8 May 2019 & Two-thirds of the largest rivers no longer flow freely-and it's harming us & 24,159 & 1900 & 110 & 520 & No \\
\hline 9 & 17 October 2018 & How the world's largest snake hunt hurts Southeast Asia's biggest lake & 21,966 & 1200 & 73 & 92 & Yes \\
\hline 10 & 5 April 2019 & Cambodia's endangered river dolphins at highest population in 20 Years & 20,178 & 6600 & 149 & 743 & Yes \\
\hline 11 & 30 July 2020 & $\begin{array}{l}\text { Many freshwater fish species have declined by } 76 \text { percent in less than } \\
\qquad 50 \text { years }\end{array}$ & 13,324 & 4600 & 97 & 450 & No \\
\hline 12 & 25 April 2019 & River sanctuaries help giant fish recover in Southeast Asia & 9777 & 1200 & 9 & 109 & No \\
\hline 13 & 4 September 2018 & An epic quest aims to find giant catfish babies & 9272 & 895 & 19 & 61 & Yes \\
\hline 14 & 29 March 2017 & Enormous fish make one of the world's largest migrations & $\mathrm{n} / \mathrm{a}$ & 6100 & 31 & 242 & Yes \\
\hline 15 & 22 March 2017 & Can the Amazon of Southeast Asia be saved? & $\mathrm{n} / \mathrm{a}$ & 5700 & 43 & 457 & Yes \\
\hline 16 & 2 July 2018 & $\begin{array}{l}\text { Critically endangered giant fish on menu at luxury restaurants (Story by } \\
\text { R. Nuwer) }\end{array}$ & $\mathrm{n} / \mathrm{a}$ & 2400 & 156 & 228 & No \\
\hline 17 & 5 April 2017 & Angkor Wat's collapse from climate change has lessons for today & $\mathrm{n} / \mathrm{a}$ & $\mathrm{n} / \mathrm{a}$ & $\mathrm{n} / \mathrm{a}$ & $\mathrm{n} / \mathrm{a}$ & Yes \\
\hline
\end{tabular}


To assess the popularity of Mekong stories, we compared user engagement for the 17 Mekong stories with 40 similar text stories recently published by National Geographic (as of 15 October 2020). To remove the effect of outliers, we compared median numbers for both sets of stories. For the Mekong stories, median numbers included 3100 engagements, 114 comments, and 310 shares, while for the non-Mekong stories, median numbers included 2700 engagements, 321 comments, and 231 shares. This suggests that Mekong stories were just as engaging as other content on National Geographic, if not more so. Among the videos developed for Mekong stories, which National Geographic posts separately on social media, those eliciting the most views were all about charismatic wildlife, including giant softshell turtles released into the wild (160,000 views), increasing numbers of endangered Irrawaddy river dolphins (76,000 views), and the water snake harvest in Tonle Sap Lake $(61,000$ views). In general, both positive or negative messaging appeared to generate reader interest and engagement: "positive" stories about the world's largest freshwater fish and increasing river turtle and dolphin populations were among the most popular stories, but so were "negative" stories about population extinctions and river degradation. Reviewing comments on Mekong stories revealed that articles about extinction and biodiversity decline elicited more negative comments, while stories reporting "positive news" generated more positive comments.

WOM also works with domestic media outlets in Cambodia, most notably with the country's most popular news website Thmey Thmey, which has over 500,000 followers. The purpose of this collaboration is to increase the knowledge, awareness, and valuation of Cambodia's natural resources among the general public of Cambodia, with a particular focus on conserving the species and ecosystems of the Lower Mekong Basin. From 2019 to 2020, WOM produced 102 stories for Thmey Thmey (many of which were also shared on the WOM Facebook page), which included fish species profiles, stories about environmental conditions, and WOM research updates (Table 3). These stories cumulatively generated 990,915 views and 71,483 likes on the Thmey Thmey website, and an additional 32,221 likes and 11,497 shares on the Thmey Thmey Facebook page.

Two of the most popular stories include an appeal to fishers to release tagged fish back into the wild for research and conservation purposes, and a Khmer folktale about the small-scale mud carp (Cirrhinus microlepis; Table 3). Another popular story described how Cambodians were incredulous that megafishes such as the giant stingray could live in the country's freshwater environments, not just in the ocean. This story illustrates how Cambodia's threatened Mekong wonders, already under-recognized, face a greater risk of remaining unknown as they decline.

Thmey Thmey benefits from the collaboration with WOM by receiving high-quality, environmentally themed content that attracts readers to their website, while the exposure has helped WOM project staff build relationships with local people. For example, project communications coordinator Chheana Chhut (paper co-author, and author of the Thmey Thmey stories) found that many vendors at fish at markets or landing sites in Kratie and Stung Treng provinces reacted angrily when he tried to photograph fish for sale without buying them, which limited opportunities to document rare fishes. However, one fish vendor in Kratie welcomed such fish photographs because the vendor had read Chhut's articles about fish species on Thmey Thmey. These fish species articles have helped elevate the profile of the unique aquatic biodiversity in Cambodia. While WOM project members' previous affiliation with National Geographic and Thmey Thmey has undoubtedly made it easier to place stories, there is also clear evidence that Mekong stories are appealing to publishers because they generate strong reader interest. 
Table 3. Engagement metrics of the 20 most viewed WOM Stories on Thmey Thmey.

\begin{tabular}{|c|c|c|c|c|c|c|c|c|}
\hline \multirow[b]{2}{*}{ No. } & \multirow[b]{2}{*}{ Publication Date } & \multirow[b]{2}{*}{ Story Title } & \multirow[b]{2}{*}{ Story Link } & \multicolumn{3}{|c|}{ Thmey Thmey Website } & \multicolumn{2}{|c|}{$\begin{array}{l}\text { Thmey Thmey } \\
\text { Facebook Page }\end{array}$} \\
\hline & & & & Views & Likes & Shares & Likes & Shares \\
\hline 1 & 30 December 2019 & $\begin{array}{l}\text { Appeal to fishermen to release tagged } \\
\text { fish if captured }\end{array}$ & $\begin{array}{l}\text { https: / / thmeythmey.com / } \text { ?page }=\text { detail\&id }=86586 \& \text { fbclid }= \\
\text { IwAR05XexbsgAOsYxJK5Jcy4I8tXPcDr4KISaMnvm2Xs-wagu2 } \\
\text { kEdHUqcAJ30, Accessed on: } 28 \text { June } 2021\end{array}$ & 154,884 & 1600 & 1 & 1516 & 3490 \\
\hline 2 & 29 June 2020 & $\begin{array}{l}\text { Khmer folktales about the small-scale } \\
\text { mud carp }\end{array}$ & $\begin{array}{l}\text { https: / / thmeythmey.com/?page=detail\&id=93175\&fbclid= } \\
\text { IwAR2r1lrGg1ECpMnkNfXUip8PjAQgCGImUQ-O7 } \\
\text { uNMPuUApRzgHqx3Rhd0S3w, Accessed on: 28 June } 2021\end{array}$ & 106,048 & 8000 & 0 & 1600 & 568 \\
\hline 3 & 23 May 2020 & $\begin{array}{l}\text { Giant fish habitats in Stung Treng } \\
\text { province reach near-threatened status }\end{array}$ & $\begin{array}{l}\text { https: / / thmeythmey.com /?page=detail\&id=92002\&fbclid= } \\
\text { IwAR0dDATFK1H8RcX9Y-MQTmgjajgObf0RczplEe7 } \\
\text { HxAowiww5YouYjK-1c8E, Accessed on: } 28 \text { June } 2021\end{array}$ & 53,744 & 6500 & 0 & 1200 & 607 \\
\hline 4 & 23 August 2020 & The giant mottled eel & $\begin{array}{l}\text { https: / / thmeythmey.com/?page=detail\&id=94930\&fbclid= } \\
\text { IwAR246yifUhev-Sr2GiNET-Dz8BAWdPqBmQc4 } \\
\text { lqNgmbplILzTAn3itXYf-fo, Accessed on: 28 June } 2021\end{array}$ & 43,524 & 1300 & 0 & 873 & 122 \\
\hline 5 & 27 December 2019 & $\begin{array}{l}\text { Laotian shad migrate } 2000 \mathrm{~km} \text { from the } \\
\text { sea up the Mekong River }\end{array}$ & $\begin{array}{c}\text { https: / / www.thmeythmey.com/?page=detail\&id=86504\&fbclid= } \\
\text { IwAR0Zud4iW8kY3bbXFoyedhhKsDzrP104pUQQgbFtLKD3 } \\
\text { 3EavMLagrWFsrd0, Accessed on: 28 June } 2021\end{array}$ & 35,025 & 0 & 0 & 1160 & 326 \\
\hline 6 & 1 and 8 May $2019^{1}$ & $\begin{array}{l}\text { Some Cambodians do not believe that } \\
\text { the largest freshwater stingray in the } \\
\text { world is present in the country }\end{array}$ & $\begin{array}{l}\text { https: / / thmeythmey.com / ?page }=\text { detail\&id=77657\&fbclid }= \\
\text { IwAR09Zexb7zCh3ueyXXfNhY0npAo7CR8580cZxXbBgW9 } \\
\text { ExjqKINY80O0_fr8, Accessed on: 28 June } 2021\end{array}$ & 39,000 & 5600 & 0 & 3014 & 700 \\
\hline 7 & 21 December 2019 & $\begin{array}{l}\text { Tagging and releasing endangered fish } \\
\text { species back into the Mekong River }\end{array}$ & $\begin{array}{c}\text { https: / / www.thmeythmey.com/?page=detail\&id=86294\&fbclid= } \\
\text { IwAR03YfqCrpPGWlvtbPWeWHSEnV1Zqs-64xB-2Rc_sSBg- } \\
\text { rHZX8Fqkc7U6Q4, Accessed on: } 28 \text { June } 2021\end{array}$ & 26,312 & 5600 & 198 & 1830 & 559 \\
\hline 8 & 4 April 2020 & $\begin{array}{l}\text { Why the Japanese call pumpkin } \\
\text { "Camboja", which means "Cambodia }\end{array}$ & $\begin{array}{l}\text { https: / / thmeythmey.com / ?page=detail\&id=90317\&fbclid }= \\
\text { IwAR3liFKxr5rp_zZXm-M5bupBK8Gm0jayq2fjck2R2Ozwx8 } \\
\text { CgtOyirHjOgKY, Accessed on: } 28 \text { June } 2021\end{array}$ & 21,996 & 2500 & 0 & 1400 & 223 \\
\hline 9 & 4 January 2020 & $\begin{array}{l}\text { Scientists first found the stonelapping } \\
\text { minnow in the Angkor area and named } \\
\text { it "Angkor Fish" in Khmer }\end{array}$ & $\begin{array}{c}\text { https: / / thmeythmey.com / ?page= detail\&id=86762\&fbclid= } \\
\text { IwAR3q4N8QJIdVsq9NDCGJKqDN5hg1q4BVt81tVKucPpJ9jD7 } \\
\text { MgUc8FTXizFE, Accessed on: } 28 \text { June } 2021\end{array}$ & 20,575 & 1300 & 0 & 618 & 223 \\
\hline
\end{tabular}


Table 3. Cont.

\begin{tabular}{|c|c|c|c|c|c|c|c|c|}
\hline \multirow[b]{2}{*}{ No. } & \multirow[b]{2}{*}{ Publication Date } & \multirow[b]{2}{*}{ Story Title } & \multirow[b]{2}{*}{ Story Link } & \multicolumn{3}{|c|}{ Thmey Thmey Website } & \multicolumn{2}{|c|}{$\begin{array}{l}\text { Thmey Thmey } \\
\text { Facebook Page }\end{array}$} \\
\hline & & & & Views & Likes & Shares & Likes & Shares \\
\hline 10 & 5 September 2020 & $\begin{array}{l}\text { What will happen to the fishing village } \\
\text { Kampong Phluk's Natural and Cultural } \\
\text { Tourism site in the future after flooded } \\
\text { forest is lost? }\end{array}$ & $\begin{array}{l}\text { https: / / thmeythmey.com / ?page=detail\&id=95346\&fbclid= } \\
\text { IwAR22W-RaYnipl_BHxhXTJEazcKRy63BHmbDQLexp-V_- } \\
\text { hLarLmZZ8YFFe9Uw, Accessed on: } 28 \text { June } 2021\end{array}$ & 17,836 & 1300 & 0 & 911 & 137 \\
\hline 11 & 29 March 2020 & $\begin{array}{l}\text { Research publication: Effect of habitat } \\
\text { and climate factors on the distribution of } \\
\text { Tonle Sap fish species }\end{array}$ & $\begin{array}{l}\text { https: / / thmeythmey.com / ?page }=\text { detail\&id }=90065 \& \text { fbclid }= \\
\text { IwAR2RGiVsPQUSOD0oS1Xfupv8ntnxK_aGNi7wKpZYcq4y8s2 } \\
\text { 9Fd4FghYfvlk, Accessed on: } 28 \text { June } 2021\end{array}$ & 17,792 & 196 & 0 & 70 & 8 \\
\hline 12 & 29 June 2020 & $\begin{array}{l}\text { If you eat breeding fish or fish eggs, you } \\
\text { are unknowingly involved in destroying } \\
\text { fish resources }\end{array}$ & $\begin{array}{l}\text { https: / / thmeythmey.com / ?page=detail\&id=92969\&fbclid= } \\
\text { IwAR18UkwLurmA2B5Q9gU3rKzbonduJwNA1xcNGyXMgs9z1 } \\
\text { 5bWxnKPIsHDYQ8, Accessed on: } 28 \text { June } 2021\end{array}$ & 15,392 & 6100 & 0 & 1100 & 414 \\
\hline 13 & 3 April 2020 & $\begin{array}{l}\text { Do you know how fish sleep and how } \\
\text { they breathe? }\end{array}$ & $\begin{array}{l}\text { https: / / thmeythmey.com / ?page=detail\&id=90287\&fbclid= } \\
\text { IwAR03YfqCrpPGWlvtbPWeWHSEnV1Zqs-64xB-2Rc_sSBg- } \\
\text { rHZX8Fqkc7U6Q4, Accessed on: } 28 \text { June } 2021\end{array}$ & 13,504 & 775 & 5 & 230 & 82 \\
\hline 14 & 16 June 2019 & $\begin{array}{l}\text { Tonle Sap Lake is home to the largest } \\
\text { freshwater fish in the world and is the } \\
\text { largest lake in Southeast Asia }\end{array}$ & $\begin{array}{c}\text { https: / / www.thmeythmey.com/?page=detail\&id=79382\&fbclid= } \\
\text { IwAR3Oh6QtmBVk5usNLdfGva2KlktXCMe3HpfA86fXPFj5 } \\
\text { wfXBCZPL02KjRd8, Accessed on: } 28 \text { June } 2021\end{array}$ & 11,222 & 6500 & & 1800 & 1116 \\
\hline 15 & 22 June 2020 & $\begin{array}{l}\text { Return to the original shelter } \\
\text { (infographic of the giant barb life cycle } \\
\text { and migration) }\end{array}$ & $\begin{array}{c}\text { https: / / thmeythmey.com / ?page=detail\&id=92754\&fbclid= } \\
\text { IwAR0hfxnCS65h6ZkqwDiEIywgttTZ9UB2b0Jm7aR2pxS9 } \\
\text { 4jednEHl3CbEs10, Accessed on: 28 June } 2021\end{array}$ & 10,912 & 263 & $` 0$ & 94 & 12 \\
\hline 16 & 11 June 2020 & $\begin{array}{l}\text { One of Earth's largest mass migrations } \\
\text { occurs along the Tonle Sap River }\end{array}$ & $\begin{array}{l}\text { https: / / thmeythmey.com/?page=detail\&id=92631\&fbclid= } \\
\text { IwAR214edvVG5UclFVcVos7g5HwY17Am9nL17AaYT9u7w4 } \\
\text { 7geqQK9mm0THHvE, Accessed on: 28 June } 2021\end{array}$ & 10,292 & 184 & 0 & 131 & 16 \\
\hline 17 & 13 April 2019 & $\begin{array}{l}\text { Kampong Luong: An attractive tourist } \\
\text { place where the environment seems to } \\
\text { be ignored }\end{array}$ & $\begin{array}{c}\text { https: / / www.thmeythmey.com/?page=detail\&id=77031\&fbclid }= \\
\text { IwAR2VL5x7slL5BI-tphl4RXp-fMRvO9XMgZgFONp5UnycOrR5 } \\
\text { zZ-9TjKyLy0, Accessed on: } 28 \text { June } 2021\end{array}$ & 10,276 & 789 & & 364 & 108 \\
\hline 18 & 2 June 2020 & $\begin{array}{l}\text { Fish spawn in deep pools in Stung Treng } \\
\text { and Kratie (infographic of the giant barb } \\
\text { life cycle and migration) }\end{array}$ & $\begin{array}{c}\text { https: / / thmeythmey.com/ ?page=detail\&id=92371\&fbclid= } \\
\text { IwAR29L8Gbur24P9FIF2FYOGslzmaAXm4GyapLd-vAYC47A8 } \\
\text { Ope_4WZHTK7iA, Accessed on: } 28 \text { June } 2021\end{array}$ & 9988 & 701 & 0 & 281 & 80 \\
\hline
\end{tabular}


Table 3. Cont.

\begin{tabular}{|c|c|c|c|c|c|c|c|c|}
\hline \multirow[b]{2}{*}{ No. } & \multirow[b]{2}{*}{ Publication Date } & \multirow[b]{2}{*}{ Story Title } & \multirow[b]{2}{*}{ Story Link } & \multicolumn{3}{|c|}{ Thmey Thmey Website } & \multicolumn{2}{|c|}{$\begin{array}{l}\text { Thmey Thmey } \\
\text { Facebook Page }\end{array}$} \\
\hline & & & & Views & Likes & Shares & Likes & Shares \\
\hline 19 & 2 March 2019 & $\begin{array}{c}\text { Tiretrack spiny eel } \\
\text { (Mastacembelus armantus) }\end{array}$ & $\begin{array}{l}\text { https: / / thmeythmey.com / ?page=detail\&id=75290\&fbclid= } \\
\text { IwAR1zEyQwvRS5jwvl7Cax02gchwynn4U-a4XXj-pQTgUEI1 } \\
\text { 5zLxd51Kcim4k, Accessed on: } 28 \text { June } 2021\end{array}$ & 9828 & 3 & & 1300 & 60 \\
\hline 20 & 9 February 2020 & $\begin{array}{l}\text { The genus Channa includes the striped } \\
\text { snakehead and giant snakehead }\end{array}$ & $\begin{array}{c}\text { https: / / thmeythmey.com / ?page=detail\&id=88076\&fbclid }= \\
\text { IwAR1W57Hc4oA7dZ0HDHZGkl6cQ2ZhP_ } \\
\text { OqLELQlknqnAMyC1RrtU5-3VFYTks, Accessed on: } 28 \text { June } 2021\end{array}$ & 9500 & 146 & 2 & 86 & 23 \\
\hline
\end{tabular}

${ }^{1}$ This story was posted twice on the Thmey Thmey website. Engagement metrics are summed for the two dates combined. 


\subsection{Visual Media}

Scientists have long utilized visual media such as photography and videos to collect data and document the scientific process, but such media can also be used to tell stories about research and conservation efforts [88]. Examples include the creation of video abstracts to summarize research efforts [89], or the addition of videos and photos to conservation-related social media posts to generate more engagement [90]. However, a general lack of photos and videos depicting freshwater animals in their natural habitat, partly due to the filming challenges posed by underwater environments, has acted as a major impediment to implementing visual media-based approaches to freshwater conservation outreach and education efforts. The majority of images and videos of freshwater animals in popular media emphasize their utilitarian value to humans (e.g., photos of fish as food or of anglers holding landed sportfish) rather than their intrinsic or ecological values [91]. This, in turn, leads to a less balanced representation of freshwater conservation issues, as major media outlets often judge potential stories on associated visual content, as well as verbal content [91]. Fortunately, online media platforms allow freshwater scientists, conservationists, and recreationists to share images of aquatic species expressing natural behaviors within their habitats, contributing to a more nuanced representation of freshwater organisms.

Video is another effective medium to connect viewers with environmental content both visually and emotionally. Well-researched and emotionally moving documentary films can highlight iconic species (e.g., Orcinus orca in the film "Blackfish") or conservation issues, and can be used in conjunction with social media campaigns to prompt social action [85]. Online platforms such as YouTube and Vimeo make it possible for organizations to easily share video content. However, the sheer volume of videos shared on these sites means additional effort, such as advertising or promotional campaigns, is required to reach and engage with new audiences [92]. More targeted alternatives include research-related film screenings at scientific meetings, as well as scientific or conservation film festivals for the public [92]. Students can also be engaged in environmental issues through youth filmmaking projects [88].

Incorporating visual communication as part of conservation projects may require purchasing camera equipment for project staff or hiring a professional to collect appropriate visual media that convey key findings or messages in an engaging manner [88]. With photo and video equipment and video editing software becoming increasingly affordable and available, the possibilities for implementing visual media-based outreach will continue to increase. Although audiences often engage with visual media remotely when it is distributed online or through media outlets, hosting photo exhibitions and film screenings can allow for impactful in-person interactions and discussions associated with visual media (Table 1). With the exception of printed visuals, digital photos and videos typically require the audience to have access to technology, which may limit their reach in rural areas. Videos, in particular, take a high level of effort to produce compared to other types of media, especially with regard to filming interviews and editing, and distribution can take a moderate level of effort, depending on whether the content is distributed online or through an in-person event. The final products can ultimately have a very large reach, especially when distributed online or through social media platforms.

\section{WOM Case Study}

The WOM project has used visual media extensively as part of its communication strategy. For example, the WOM Flickr account (https: / /www.flickr.com/mekongwonders, Accessed on: 28 June 2021) includes nearly 4000 images taken by project staff and partners that are frequently used for outreach materials and social media. The project has also partnered with Thai photographer Suthep Kritsanavarin (paper co-author) to produce high-quality photography and videos documenting the daily lives of people connected to the Mekong River and Tonle Sap Lake, and to lead photography training workshops for students, academics, conservation practitioners, and media personnel. Kritsanavarin's 
photographs and videos have been used in exhibitions, television broadcasts, and social media campaigns, and to illustrate books about the Mekong. By depicting the lives and livelihoods of people such as fishers and farmers who depend on the Mekong ecosystem, these photographs evoke the connection between people and nature, often conveying the elements of a story without the need for captions. Such work requires developing trust with the subjects before documenting them to elicit their personalities on film.

The resulting visuals effectively use stunning contrast to capture dramatic environmental changes in the Mekong Basin, as well as the nature of the threats it faces. Kritsanavarin produced a series of paired photographs taken in different seasons at the same location on the Tonle Sap Lake to document the remarkable seasonal fluctuations in the lake's water level, and the resulting changes to the lakeside communities that live in floating houses or stilt houses. The photos communicated the natural rhythms of the river that are part of daily life for those that depend on it. One such pair of aerial drone photos was among the most popular WOM Facebook posts (Figure 4, Table 4) and documents how the Kampong Luong floating village in Pursat Province moves as far as three kilometers with rising floodwaters in Tonle Sap Lake). Kritsanavarin's imagery documents the tenuousness of Cambodia's natural resources, such as verdant flooded forest being converted into agricultural fields, landscapes parched by drought, or fishers catching some of the world's largest freshwater fishes that are approaching extinction.

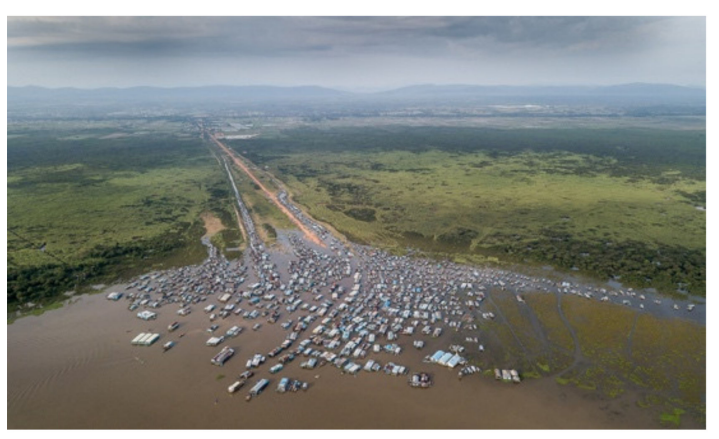

(a)

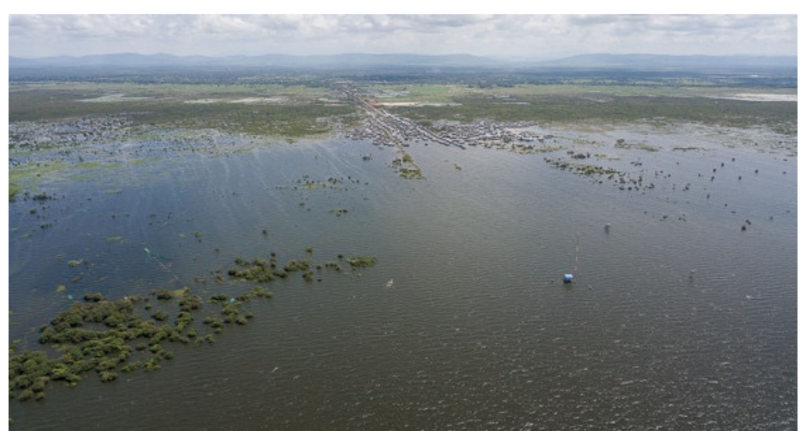

(b)

Figure 4. Two pictures of the Kampong Luong floating village in Pursat Province on Tonle Sap Lake by photographer Suthep Kritsanavarin shared on WOM social media. (a) Photo taken in June at the beginning of the rainy season; (b) photo taken in September. On average, the village moves back as far as three kilometers during the rainy season.

WOM has also worked to produce and share 69 videos, including 53 short videos under $5 \mathrm{~min}$, and 16 longer videos and mini-documentaries. While short films that highlight a single event or idea can grab the attention of viewers on social media, longer documentaries allow for a more in-depth exploration of a topic. Visual storytelling through video can convey the serious challenges posed by drought or wildlife trafficking, and also show hopeful stories, such as the connection between an animal keeper and a rescued elephant, or fishers releasing large endangered fish. While project videos are uploaded to YouTube, Facebook has been the most popular dissemination platform for project content, including videos (see Social Media section below). Videos were disproportionately popular on Facebook - although they represented just $12 \%$ of total posts, videos made up $60 \%$ of the 2 Facebook posts with the highest nonpaid (organic) reach (Table 4). The most popular video featured project lead Zeb Hogan narrating a visit to a Fish Conservation Area in Tonle Sap Lake (Table 4), which may reflect the benefit of a charismatic, well-known narrator on camera, as well as a positive conservation story showing the large numbers of fish in the protected area. 


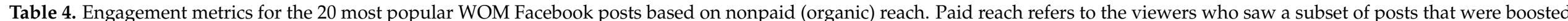
with paid advertising.

\begin{tabular}{|c|c|c|c|c|c|c|c|c|c|c|}
\hline No. & Date Posted & Post Title and/or Description & Post Link & Post Type & $\begin{array}{l}\text { Lifetime Post } \\
\text { Organic Reach }\end{array}$ & $\begin{array}{l}\text { Lifetime Post } \\
\text { Paid Reach }\end{array}$ & $\begin{array}{l}\text { Lifetime Post } \\
\text { Total Reach }\end{array}$ & Likes & Shares & Comments \\
\hline 1 & 7 December 2020 & $\begin{array}{l}\text { Under the Surface of the Tonle } \\
\text { Sap River: A post documenting } \\
\text { fishermen catching trash in the } \\
\text { nets of the Cambodian } \\
\text { dai fishery }\end{array}$ & $\begin{array}{l}\text { https://www. } \\
\text { facebook.com/ } \\
\text { MekongWonders/ } \\
\text { posts/3540613329 } \\
\text { 353667, Accessed } \\
\text { on: 28 June } 2021\end{array}$ & Photo & 348,968 & 0 & 348,968 & 5084 & 1993 & 201 \\
\hline 2 & 31 March 2020 & $\begin{array}{l}\text { A short video of Dr. Zeb Hogan, } \\
\text { WOM project lead, with } \\
\text { fisherman on the Tonle Sap Lake } \\
\text { describing how fish conservation } \\
\text { areas can boost fish populations }\end{array}$ & $\begin{array}{l}\text { https://www. } \\
\text { facebook.com/ } \\
\text { MekongWonders/ } \\
\text { posts /2851177898 } \\
\text { 297217, Accessed } \\
\text { on: 28 June } 2021 \\
\end{array}$ & Video & 133,057 & 0 & 133,057 & 393 & 54 & 12 \\
\hline 3 & 3 August 2020 & $\begin{array}{l}\text { A video of Ms. Sothira Seng, } \\
\text { USAID Project Specialist, visiting } \\
\text { a nursery pond for endangered } \\
\text { fishes and explaining a captive } \\
\text { rearing program }\end{array}$ & $\begin{array}{l}\text { https://www. } \\
\text { facebook.com/ } \\
\text { MekongWonders/ } \\
\text { posts/3165770746 } \\
\text { 837929, Accessed } \\
\text { on: 28 June 2021 }\end{array}$ & Video & 75,502 & 0 & 75,502 & 756 & 167 & 22 \\
\hline 4 & 30 July 2020 & $\begin{array}{l}\text { Taking Care of Breeding Fishes in } \\
\text { Stung Treng: A short video with } \\
\text { the Cambodian Fisheries } \\
\text { Administration describing the } \\
\text { closed-season fishing regulations } \\
\text { in Stung Treng to protect } \\
\text { fish breeding }\end{array}$ & $\begin{array}{l}\text { https:/ / www. } \\
\text { facebook.com/ } \\
\text { MekongWonders / } \\
\text { posts /3161347667 } \\
\text { 280237, Accessed } \\
\text { on: 28 June } 2021\end{array}$ & Video & 63,271 & 0 & 63,271 & 1560 & 545 & 47 \\
\hline 5 & 31 August 2020 & $\begin{array}{l}\text { Pair of drone photographs } \\
\text { showing the dramatic movement } \\
\text { of Kampong Luong floating } \\
\text { village in Pursat Province on } \\
\text { Tonle Sap Lake with the change } \\
\text { in water level between dry and } \\
\text { wet seasons }\end{array}$ & $\begin{array}{l}\text { https://www. } \\
\text { facebook.com/ } \\
\text { MekongWonders/ } \\
\text { posts /3157672790 } \\
\text { 981058, Accessed } \\
\text { on: 28 June } 2021\end{array}$ & Photo & 51,527 & 0 & 51,527 & 994 & 300 & 171 \\
\hline
\end{tabular}


Table 4. Cont.

\begin{tabular}{|c|c|c|c|c|c|c|c|c|c|c|}
\hline No. & Date Posted & Post Title and/or Description & Post Link & Post Type & $\begin{array}{c}\text { Lifetime Post } \\
\text { Organic Reach }\end{array}$ & $\begin{array}{l}\text { Lifetime Post } \\
\text { Paid Reach }\end{array}$ & $\begin{array}{l}\text { Lifetime Post } \\
\text { Total Reach }\end{array}$ & Likes & Shares & Comments \\
\hline 6 & 18 August 2020 & $\begin{array}{l}\text { Cambodia's Vanishing Flooded } \\
\text { Forest: A short video describing } \\
\text { a WOM research publication } \\
\text { about deforestation in Cambodia }\end{array}$ & $\begin{array}{l}\text { https://www. } \\
\text { facebook.com/ } \\
\text { MekongWonders/ } \\
\text { posts/3218756948 } \\
\text { 205975, Accessed } \\
\text { on: 28 June 2021 }\end{array}$ & Video & 43,674 & 0 & 43,674 & 926 & 290 & 14 \\
\hline 7 & 3 March 2020 & $\begin{array}{l}\text { Photo series of five giant Mekong } \\
\text { fish species, including the giant } \\
\text { barb, the giant freshwater } \\
\text { stingray, and the Mekong giant } \\
\text { catfish - the post discusses the } \\
\text { ecological and cultural } \\
\text { importance of these species }\end{array}$ & $\begin{array}{l}\text { https://www. } \\
\text { facebook.com/ } \\
\text { MekongWonders / } \\
\text { posts / 2792640507 } \\
\text { 484290, Accessed } \\
\text { on: 28 June } 2021\end{array}$ & Photo & 42,529 & 0 & 42,529 & 1325 & 290 & 27 \\
\hline 8 & 27 September 2020 & $\begin{array}{c}\text { A cartoon depicting the harms of } \\
\text { illegal electrofishing on } \\
\text { Mekong fishes }\end{array}$ & $\begin{array}{l}\text { https://www. } \\
\text { facebook.com/ } \\
\text { MekongWonders/ } \\
\text { posts/3336269046 } \\
\text { 454764, Accessed } \\
\text { on: } 28 \text { June } 2021\end{array}$ & Photo & 41,507 & 0 & 41,507 & 1203 & 368 & 25 \\
\hline 9 & 30 April 2020 & $\begin{array}{l}\text { The King of Fishes: A short video } \\
\text { interviewing a Cambodian } \\
\text { fisherman who shares his } \\
\text { experience of releasing an } \\
\text { endangered giant barb that he } \\
\text { caught in his net }\end{array}$ & $\begin{array}{l}\text { https://www. } \\
\text { facebook.com/ } \\
\text { MekongWonders / } \\
\text { posts/292200676121 } \\
\text { 4330, Accessed on: } \\
\text { 28 June } 2021\end{array}$ & Video & 39,427 & 0 & 39,427 & 838 & 260 & 14 \\
\hline 10 & 23 October 2020 & $\begin{array}{l}\text { A series of photos from a World } \\
\text { Fish Migration Day } 2020 \\
\text { celebration, including the release } \\
\text { of } 7000 \text { juvenile fish into the } \\
\text { Mekong River, and a short video } \\
\text { message from WOM project lead } \\
\text { Dr. Zeb Hogan }\end{array}$ & $\begin{array}{l}\text { https://www. } \\
\text { facebook.com/ } \\
\text { MekongWonders/ } \\
\text { posts/3419219608 } \\
\text { 159707, Accessed on: } \\
\text { 28 June } 2021\end{array}$ & Photo & 31,870 & 0 & 31,870 & 1088 & 150 & 14 \\
\hline
\end{tabular}


Table 4. Cont.

\begin{tabular}{|c|c|c|c|c|c|c|c|c|c|c|}
\hline No. & Date Posted & Post Title and/or Description & Post Link & Post Type & $\begin{array}{c}\text { Lifetime Post } \\
\text { Organic Reach }\end{array}$ & $\begin{array}{c}\text { Lifetime Post } \\
\text { Paid Reach }\end{array}$ & $\begin{array}{c}\text { Lifetime Post } \\
\text { Total Reach }\end{array}$ & Likes & Shares & Comments \\
\hline 11 & 6 August 2020 & $\begin{array}{l}\text { Recreational Fishing in the } \\
\text { Cambodian Mekong: A short } \\
\text { video describing recreational } \\
\text { fishing along the banks of the } \\
\text { Mekong River in Cambodia }\end{array}$ & $\begin{array}{l}\text { https://www. } \\
\text { facebook.com/ } \\
\text { MekongWonders / } \\
\text { posts/318369050171 } \\
\text { 2620, Accessed on: } \\
\text { 28 June } 2021\end{array}$ & Video & 30,767 & 0 & 30,767 & 723 & 144 & 19 \\
\hline 12 & 22 July 2020 & $\begin{array}{c}\text { Threats to the Painted Stork: A } \\
\text { story describing human threats } \\
\text { to the endangered Painted Stork } \\
\text { in Cambodia, including a photo } \\
\text { of dead birds captured } \\
\text { by poachers }\end{array}$ & $\begin{array}{l}\text { https://www. } \\
\text { facebook.com/ } \\
\text { MekongWonders/ } \\
\text { posts/3123229497 } \\
758721 \text {, Accessed } \\
\text { on: 28 June } 2021\end{array}$ & Photo & 30,086 & 0 & 30,086 & 873 & 215 & 44 \\
\hline 13 & 25 June 2019 & $\begin{array}{l}\text { Making Smoked Fish: A short } \\
\text { video interview with a } \\
\text { Cambodian fisherman about } \\
\text { producing smoked catfish, a } \\
\text { staple in many } \\
\text { Cambodian communities }\end{array}$ & $\begin{array}{l}\text { https://www. } \\
\text { facebook.com/ } \\
\text { MekongWonders/ } \\
\text { posts/2203621213 } \\
\text { 052892, Accessed } \\
\text { on: 28 June } 2021 \\
\end{array}$ & Video & 26,680 & 64,453 & 87,046 & 1279 & 366 & 25 \\
\hline 14 & 12 December 2019 & $\begin{array}{l}\text { Mekong Conservation Hero Sun } \\
\text { Visal: A video interview with Mr. } \\
\text { Sun Visal, who works to } \\
\text { conserve waterbirds with the } \\
\text { Wildlife Conservation Society } \\
\text { in Cambodia }\end{array}$ & $\begin{array}{l}\text { https://www. } \\
\text { facebook.com/ } \\
\text { MekongWonders/ } \\
\text { posts/254331048241 } \\
\text { 7295, Accessed on: } \\
\text { 28 June } 2021 \\
\end{array}$ & Video & 23,050 & 37,488 & 59,489 & 1285 & 315 & 90 \\
\hline 15 & 20 January 2020 & $\begin{array}{l}\text { Mekong Conservation Hero } \\
\text { Thach Phanara: A video } \\
\text { interview with Mr. Thach } \\
\text { Phanara, who works to conserve } \\
\text { freshwater fishes with the } \\
\text { Fisheries Administration } \\
\text { in Cambodia }\end{array}$ & $\begin{array}{l}\text { https:/ /www. } \\
\text { facebook.com/ } \\
\text { MekongWonders / } \\
\text { posts / 2697138237 } \\
\text { 034518, Accessed } \\
\text { on: 28 June } 2021\end{array}$ & Video & 20,971 & 52,543 & 74,657 & 1019 & 249 & 82 \\
\hline
\end{tabular}


Table 4. Cont.

\begin{tabular}{|c|c|c|c|c|c|c|c|c|c|c|}
\hline No. & Date Posted & Post Title and/or Description & Post Link & Post Type & $\begin{array}{l}\text { Lifetime Post } \\
\text { Organic Reach }\end{array}$ & $\begin{array}{l}\text { Lifetime Post } \\
\text { Paid Reach }\end{array}$ & $\begin{array}{l}\text { Lifetime Post } \\
\text { Total Reach }\end{array}$ & Likes & Shares & Comments \\
\hline 16 & 15 September 2020 & $\begin{array}{l}\text { The Changing World of } \\
\text { Cambodia's Tonle Sap Lake: A } \\
\text { video following Dr. Zeb Hogan, } \\
\text { WOM project lead, to learn about } \\
\text { the water snake harvest in Tonle } \\
\text { Sap Lake. }\end{array}$ & $\begin{array}{l}\text { https://www. } \\
\text { facebook.com/ } \\
\text { MekongWonders/ } \\
\text { posts/3302768393 } \\
\text { 138163, Accessed on: } \\
\text { 28 June } 2021\end{array}$ & Video & 19,250 & 0 & 19,250 & 422 & 130 & 8 \\
\hline 17 & 30 October 2020 & $\begin{array}{c}\text { Celebrating World Fish } \\
\text { Migration Day 2020: A video } \\
\text { describing a release of } \\
\text { endangered juvenile fish into the } \\
\text { Mekong River to celebrate World } \\
\text { Fish Migration Day } \\
\end{array}$ & $\begin{array}{l}\text { https://www. } \\
\text { facebook.com/ } \\
\text { MekongWonders/ } \\
\text { posts/3437608089 } \\
\text { 654192, Accessed } \\
\text { on: 28 June } 2021\end{array}$ & Video & 18,764 & 0 & 18,764 & 224 & 35 & 3 \\
\hline 18 & 17 August 2020 & $\begin{array}{l}\text { A pair of drone photographs of } \\
\text { Kampong Pluk Village in Siem } \\
\text { Reap Province, Cambodia, } \\
\text { showing the change in water } \\
\text { level from the start of the rainy } \\
\text { season to the peak of the } \\
\text { rainy season }\end{array}$ & $\begin{array}{l}\text { https://www. } \\
\text { facebook.com/ } \\
\text { MekongWonders/ } \\
\text { posts/3157599464 } \\
\text { 321724, Accessed } \\
\text { on: 28 June } 2021\end{array}$ & Photo & 18,590 & 0 & 18,590 & 473 & 112 & 1 \\
\hline 19 & 27 July 2020 & $\begin{array}{l}\text { A post describing the Living } \\
\text { Planet Index Report about } \\
\text { migratory fishes describing an } \\
\text { average } 76 \% \text { decline in migratory } \\
\text { fish populations around the } \\
\text { world since } 1970\end{array}$ & $\begin{array}{l}\text { https://www. } \\
\text { facebook.com/ } \\
\text { MekongWonders/ } \\
\text { posts/3154564824 } \\
\text { 625188, Accessed } \\
\text { on: 28 June } 2021 \\
\end{array}$ & Photo & 18,264 & 0 & 18,264 & 637 & 91 & 6 \\
\hline 20 & 27 January 2020 & $\begin{array}{l}\text { Mekong Conservation Hero Aing } \\
\text { Sereyrath: A video interview } \\
\text { with Ms. Aing Sereyrath who } \\
\text { works to engage youth in } \\
\text { conservation with Young Eco } \\
\text { Ambassador in Cambodia }\end{array}$ & $\begin{array}{l}\text { https://www. } \\
\text { facebook.com/ } \\
\text { MekongWonders/ } \\
\text { posts/2705188166 } \\
\text { 229525, Accessed } \\
\text { on: 28 June 2021 }\end{array}$ & Video & 17,738 & 50,610 & 67,367 & 1239 & 223 & 37 \\
\hline
\end{tabular}


Video can also be an effective medium for communicating research results. Among the five most popular project videos was one describing a study of patterns in Cambodia's deforestation rates [23], with a focus on the flooded forest of Tonle Sap (Table 4). Another popular project video was one titled "The King of Fishes", in which a Cambodian fisherman describes releasing an endangered giant barb, the national fish of Cambodia, caught in his net as a way of bringing good karma or merit (Table 4). In addition to depicting the connection between people and nature, such videos also convey values that motivate local people to participate in conservation activities, such as promoting food and livelihood security, protecting cultural heritage, and providing for future generations.

One lesson learned is the value of drone photography and videography for offering a unique aerial perspective of broad landscapes such as wetlands, floodplains, and the Tonle Sap Lake. Such perspectives allow viewers to visualize the scale and connectivity of these important freshwater landscapes, which are not always apparent on the ground. Aerial photography also provides striking visuals that convey the scale of environmental impacts, such as documenting the loss of flooded forest habitat around Tonle Sap Lake due to the conversion to agriculture, as well as dry and cracked farm fields parched by drought. Another key lesson is the importance of producing bilingual videos to make them accessible in the language of the primary audience (in this case, Khmer). Most project videos are produced in Khmer with English subtitles, or vice versa, and these bilingual videos have received much more engagement than English-only videos. In fact, WOM regularly receives requests for translations of English-only videos from Cambodian viewers. While translation is an extra step that can be time-consuming, and merits hiring a translator specifically for this task, it is extremely valuable for broadening the reach of the videos. Enabling viewers to understand a topic in their native language helps them form a relationship to the material and connects the stories to local culture. Having an English language option as well helps communicate the value of Cambodia's Mekong resources to a more global audience.

\subsection{Social Media}

Social media represents a shift from traditional, largely noninteractive forms of communication, such as print and television, to a broadly accessible, user-driven network that allows for interactions between organizations, individuals, and communities. Social media platforms such as Facebook, Twitter, Instagram, YouTube, and Flickr have the potential to engage and inform the public on conservation issues, and to serve as valuable sources of ecological and sociological data to inform conservation actions. Conservation organizations are increasingly using social media tools to improve public awareness of conservation issues and distribute the findings of conservation research [93], and such tools can also improve the accountability of public officials and individuals in response to conservation crises [94]. Moreover, engagement of the public in biodiversity monitoring and conservation using social media tools has been cited as having led to a "rebirth of natural history" in countries around the world [95]. Such platforms allow the public to interact with experts in the field of conservation science [96], and can be used to assess public perceptions of conservation actions [97]. Social media also shows substantial, if underutilized, potential for informing conservation research, management, and planning efforts [98-103]. However, successful development and implementation of the most effective methodologies require accounting for numerous potential challenges.

In order to leverage social media to its full potential, a strategic approach is required beyond simply creating a social media presence, such as taking steps to prompt interactions and stimulate discussion [90]. Such a strategy might begin with efforts to understand the behavior of different demographic sectors of an organization's online audience in order to strategically target each group [104-106]. Strategic elements can also include identifying which types of content (such as photos and videos) stimulate more discussion and user interactions [90], timing the sharing of posts on days and times with the highest user 
engagement [107], and aiming for frequency and regularity of posts, which can increase engagement [108].

In terms of content related to wildlife research and conservation, more charismatic species, particularly birds and mammals, tend to receive far more attention than other taxa $[93,109]$. Furthermore, larger bodied animals receive much more attention than smaller ones, and both factors lead to social media users interacting with a significantly biased subsample of conservation issues and science [87]. In the aquatic realm, this poses a challenge for drawing attention to taxa such as fishes. However, the Mekong is home to more large-bodied freshwater fishes than any river on earth, and social media content related to these species has indeed proved to be very popular (Table 4, see Case Study below). Critically, generating engagement alone does not guarantee achieving outreach goals, such as informing the public on key conservation issues [110], and the strategic development of messaging is essential. Consideration must be given to the specific knowledge an organization is seeking to transmit, whether highlighting threats from human activities, or effectively describing conservation efforts and methodologies to improve public understanding [110].

While social media engages audience members remotely and requires access to technology, such digital interactions are becoming increasingly common and normal. A moderate amount of effort is required to develop and curate social media content, particularly in a strategic way to include elements such as visual media and themed posts. However, comparatively little effort is needed to distribute the content via social media platforms, and there is potential to reach hundreds of thousands of people, especially if stories go "viral". Overall, successfully leveraging the power of social media does require encouraging public participation. As such, organizations may assign one or more individuals to respond to user posts and to provide up-to-date information. This can be time-consuming, but maximizes opportunities for productive dialogue [90].

\section{WOM Case Study}

While the WOM uses several social media platforms, including Instagram, Twitter, and YouTube, the majority of project communication and outreach takes place via Facebook. This platform has the largest reach in Cambodia, with 8.8 million accounts reported among a national population of 16.48 million people in 2019 [29]. With the help of paid advertising and the regular posting of new content, WOM Facebook page followers have grown to over 155,000 people as of June 2021. Of these followers, $80 \%$ are in Cambodia, $9 \%$ are in Vietnam, $5 \%$ are in Thailand, and $2 \%$ are in Laos. Facebook serves as a platform for disseminating a variety of media products developed by the project, including photos, videos, original stories, infographics, and cartoons (Table 4). The Facebook page functions as a de facto project website and is the most regularly updated source of information about the project. Between February 2017 and February 2021, WOM shared 568 posts on Facebook. Collectively, these posts had a reach of 3.2 million (including an unpaid reach of 2.3 million), and generated 150,854 engagements (likes, shares, or comments).

Types of stories posted to the WOM Facebook include updates of project activities or events, summaries of key findings or recent research, profiles of project team members, profiles of unique fish and wildlife species, and original stories reported by the project. Stories also draw attention to the impacts of human actions on the health of the aquatic environment, such as the harms of illegal destructive fishing, flooded forest clearing, plastic pollution, and discarded fishing gear. Some of the posts were promoted with paid Facebook advertising to increase their reach. To account for this in assessing the project's most engaging stories, posts were ranked based on their organic, or nonpaid reach. The most popular post was a series of photos and a short story about fishers in the Tonle Sap River catching more plastic than fish in their nets, which reached over 348,000 peoplenearly three times more than the next most popular post (Table 4). The viral nature of this story reflected the surprise and concern of Cambodians reacting to the magnitude of plastic pollution in the Tonle Sap River. While terrestrial trash is more visible in Cambodia, 
comments reflected that people were unaware about the extent of the trash in the Tonle Sap River, which is the main source of fish caught for food in the country. Concerns about contamination of their food source prompted people to share the post and make complaints to people or organizations in charge of Phnom Penh's waste management. The story was also shared by several news outlets and conservation organizations, which helped increase its viral reach.

Popular posts included both positive stories, such as the release of endangered juvenile fish from captive rearing ponds, as well as negative stories about the threats of trash, deforestation, and the poaching of waterbirds (Table 4). Several stories had explicit conservation messages, such as a popular cartoon communicating the harms of illegal electrofishing practices (Figure 5, Table 4). Technical profiles about various fish species that included identifying characteristics and notes on biology, habitats, and threats were well received, reflecting an interest among Cambodians in learning about their local aquatic biodiversity. The most popular of these was a post about the tinfoil barb (Barbonymus schwanenfeldii), a relatively common Mekong fish that is popular with aquarists, which had an organic reach of 12,952, and 2112 engagements. Longer content was sometimes split into multiple posts in a series. For instance, a series of infographics was shared about the life cycle of the giant barb (Figure 5). In this case, the first post in the six-part series was most popular, perhaps because it was the most novel. Releasing posts in series or around themes, such as Earth Day, also helped boost engagement. Effort was made to translate all posts into Khmer and English. While time-consuming, this helped increase engagement among the primary audience of Cambodians. As many of the comments and questions on the page were posted in Khmer, bilingual moderators were needed to engage with the audience.

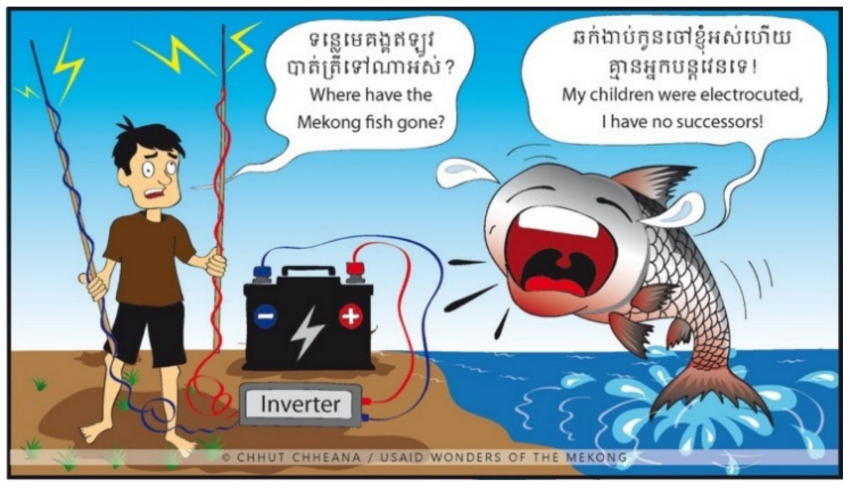

(a)

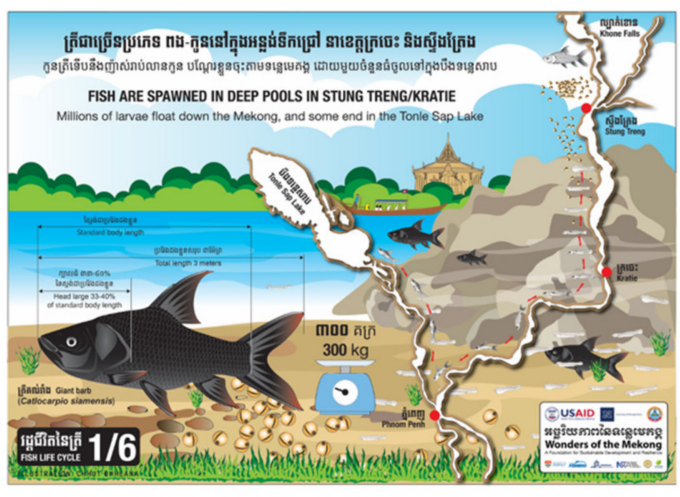

(b)

Figure 5. Examples of graphics from the Wonders of the Mekong project shared on social media, including (a) an awarenessraising cartoon about the harms of illegal electrofishing; (b) the first in a series of infographics about the life cycle of the giant barb.

\section{Cross-Cutting Outreach Strategies \\ 4.1. Promoting Local Conservation Heroes}

One way to help foster a connection to conservation is to highlight the work of people on the frontlines of conservation activities. Raising the profile and developing the skills of local researchers and conservationists are particularly important to sustain on-the-ground conservation activities in the developing world. For example, in order to conserve the oceans, "every coastline needs a hero" [111]. Identifying and training "homegrown" leaders is crucial for building international conservation capacity, because those who are most familiar with the local social and political issues facing conservation initiatives, as well as the cultural attitudes of local people, may be best poised to address them [74]. The complexity and challenging nature of conservation problems necessitate conservation scientists to receive training to move beyond research and collaborate and communicate 
with nonscientists in innovative ways [112]. Interdisciplinary training and networking, including communication and interpersonal skills, are viewed as important tools for developing conservation leaders because conservationists must often persuade or encourage others to take particular actions to help the environment [74]. A diversity of in-person and media-based communication tools can be used to train and support local conservationists in sharing their stories. These local conservationists can serve as both environmental ambassadors and role models for others to pursue conservation career tracks.

\section{WOM Case Study}

WOM developed the Mekong Conservation Heroes program as an effort to highlight inspiring Cambodians working to study, protect, or raise awareness about the Mekong River's unique ecosystem, biodiversity, habitats, and cultural heritage. A lack of women in highly visible conservation leadership roles can make it challenging for women and girls seeking inspiration from female role models [74]; therefore, the Mekong Conservation Heroes program made a concerted effort to highlight Cambodian women engaged in conservation. In 2018-2019, a cohort of six Heroes were selected through a nomination and evaluation process, in which male candidates greatly outnumbered females. The final group of two women and four men spanned a range of ages and experience, and their diverse areas of focus included fish, water birds, turtles, wetland conservation, livelihood development, and awareness-raising. As a multimedia component of the program, the Heroes received training in how to communicate the stories of their work through writing blog posts, filming videos, taking photos, giving on-camera interviews, and public speaking (Figure 6). An online multimedia profile was then created for each Hero, featuring both written and video biographies, as well as blog posts and photographs highlighting his or her work (https:/ / www.mekongfishnetwork.org/mekong-conservation-heroes/, Accessed on: 28 June 2021). All materials were translated into both English and Khmer to reach a broad audience. The program incorporated in-person outreach by inviting the Heroes to speak at a 2019 Mekong Festival event, and the Heroes have also given talks about their work at schools and community groups, and at an award ceremony. In 2020, a new cohort of three women and three men was selected from a pool of 13 nominations, and their profiles will be developed and promoted in 2021.

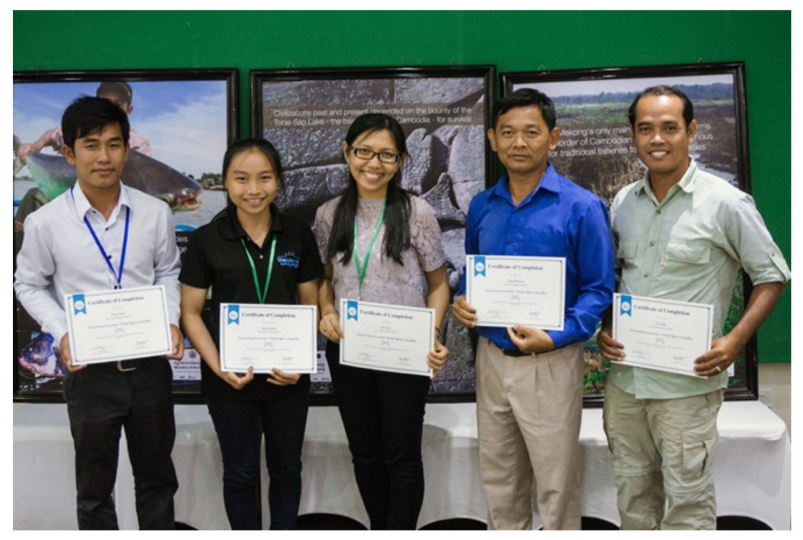

(a)

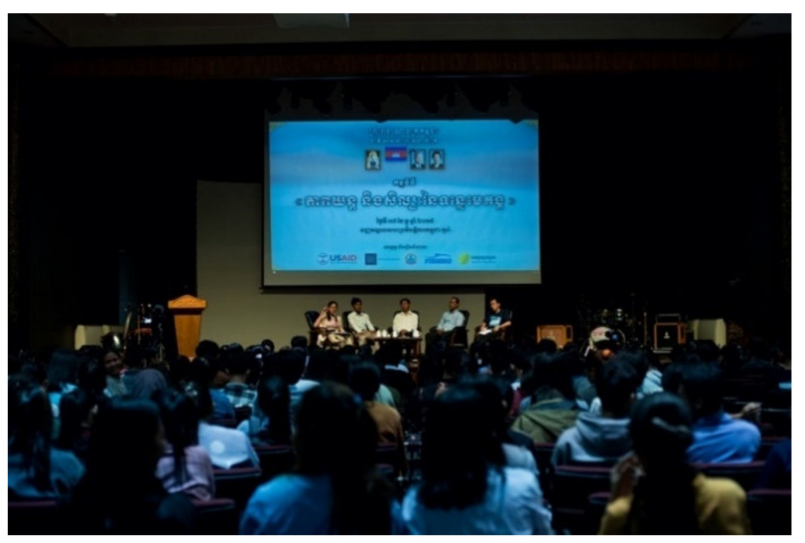

(b)

Figure 6. Honorees of the WOM Mekong Conservation Heroes program: (a) Conservation Heroes after completing a training in conservation storytelling; (b) Mekong Conservation Heroes participating in a panel discussion during a WOM conservation outreach festival in Phnom Penh.

Video interviews provided an intimate opportunity for the Conservation Heroes to share their stories. People who may not have their own personal connection to nature may find it easier to relate to another person's experiences; therefore, the personal stories and passion of conservation leaders may help indirectly inspire a connection to nature in others. 
Video interviews with the Mekong Conservation Heroes allowed Cambodians to hear from local role models about why conserving the country's natural resources is important and meaningful. Filming interviews in Khmer was especially important for producing these video biographies, as it was possible to highlight a more diverse spectrum of Heroes without a requirement for English proficiency, and the interview subjects could focus on the messages they wanted to convey, rather than translating their messages into English.

The Mekong Conservation Heroes program has been recognized as one of the most popular and successful elements of the WOM project. WOM Facebook posts with the hashtag \#conservationheroes exhibited the most relative engagement compared to other hashtags, and three of the six Mekong Conservation Hero video profiles from the first cohort were among the project's 20 most popular Facebook posts (Table 4). The WOM video that garnered the most comments on Facebook was the award acceptance speech of female Mekong Conservation Hero Seila Chea (paper co-author), who also wrote the project's most popular Facebook post about plastic pollution (Table 4). The program has provided local role models for the next generation of conservationists in Cambodia, and is a particularly valuable platform for highlighting female conservation leaders in a country where gender norms can limit career opportunities for women. Several of the Heroes' stories were picked up by Cambodian news media outlets. One limitation to this approach is the amount of time and effort required to complete and promote an in-depth profile of each Hero, which results in a relatively small number of people being featured in each cohort. However, the benefit of the program is to amplify these stories, such that one person's story can reach thousands of people. This type of cross-cutting strategy that draws on both in-person and media-based approaches to tell the stories of local conservationists could be replicated in other countries.

\section{Discussion}

Conservation organizations wishing to leverage the communication tools discussed in this review can evaluate them based on their strengths and weaknesses. In terms of resources and effort required, an inherent tradeoff exists between the depth of in-person engagement and reach. In-person strategies have the benefit of allowing for two-way communication, which permits audience members to dialogue, ask questions, and feel like they are part of an experience rather than just receiving informational products [2]. In-person activities may take more effort and reach fewer people but can have a more lasting impact on the people they reach, and they are considered some of the best methods for reaching new audiences about scientific topics $[63,65]$. Conversely, media-based, remote approaches can have a very large reach with a relatively small amount of effort. Digital tools such as social media allow opportunities for audience members to engage with the material, conservation organizations, and each other remotely [2], and in-person and mediabased tools can be used to complement each other. For example, social media can be used to generate interest and awareness about in-person events. Communication tools may be more powerful when combined, and ultimately adopting a portfolio of different strategies in a coordinated manner is the best way to reach diverse audience segments $[33,88]$.

WOM was designed to build an informed constituency among government and civil society in Cambodia to advocate for and pursue sustainable development options. Specific goals of the project include: (1) increased understanding by the public and government in Cambodia about the value of ecosystem services provided by the Mekong River and its watershed and biodiversity; (2) improved public dialogues and forums for discussing sustainable development in the region, including participatory discussions about the factors helping and hindering conservation efforts; and (3) increased knowledge supported by research of the economic, socio-cultural, and environmental importance of the Mekong's natural resources and consequences of their degradation. Communication and outreach efforts have been fundamental to achieving these goals.

The WOM project benefited from using multiple forms of media to highlight, develop, and amplify a direct personal connection between Cambodians and nature, as well as an 
understanding of the benefits people derive from nature. The project has made an effort to communicate the results of its interdisciplinary research efforts related to fisheries [22,40,41], deforestation [23], water quality [113], and evaluating ecosystem services in the context of hydropower development [15]. Distilling, translating, and communicating WOM research results for a Cambodian audience have helped develop the project's reputation as a trusted, credible source for information about the Mekong on social media. Providing up-to-date information and ensuring its accuracy are important for establishing this credibility, which is also reflected in the project's ability to engage key conservation stakeholders in the Cambodian government, such as the Fisheries Administration and other agencies of the Ministry of Agriculture, Forestry and Fisheries, as well as the Ministry of Environment. Building such partnerships among government and community stakeholders can help institutionalize and sustain conservation programs [5]. At the same time, highlighting personal stories of local people engaged in conservation, whether researchers studying wildlife in the field, or fishers who release endangered fishes that they happen to catch, can help inspire Cambodians and other audiences on an emotional level and build support for such conservation activities.

The WOM project demonstrates how information about the Mekong River and its biodiversity can readily be adapted to a range of outreach tools. In particular, the project has tapped into the potential for the Mekong's many megafish species to serve as important ambassadors for freshwater conservation [36]. The project also illustrates how different strategies can be used to elevate the profile of Mekong issues among both local (Cambodian) and global audiences. Language is particularly important in this context, and providing bilingual content in Khmer and English has been instrumental in reaching both Cambodian and international audiences. A scarcity of Khmer language materials has previously been identified as a limiting factor for environmental education in Cambodia [25], underscoring the value of investing in the translation of content originally developed in English, as well as developing materials directly in local languages.

The environmental issues facing the Mekong River are transboundary, and conservation solutions must ultimately come from multiple countries working together. WOM shares the results of its studies with the Mekong River Commission and the Mekong Fish Network, which disseminate information across the Lower Mekong Basin countries. However, one of the biggest logistical challenges to international communication is identifying key audiences within each country and communicating targeted conservation messages in local languages. What the WOM project has accomplished in Cambodia is a model that could be replicated in neighboring countries, and coordinated campaigns could then be launched across countries with shared messaging in multiple languages. While WOM social media stories currently reach people in all Lower Mekong Basin countries, the representation of countries other than Cambodia is limited in part due to the focus on posting stories in Khmer and English. However, effort will be made in the future to translate key stories into multiple languages to increase the distribution of information in other Lower Mekong Basin countries.

While WOM has helped to raise awareness and improve knowledge about the Mekong River ecosystem, quantifying the total impact of these communications efforts is challenging. The presumed link between knowledge and behavior change may be considered overly simplistic, and the most effective messages convey information that motivates shifts in behavior [114]. Few studies have attempted to empirically evaluate the effect of environmental education and outreach efforts on knowledge, attitudes, and behavior, or on their larger conservation impact [4]. While it is possible to determine the number of people reached with a particular communication tool, techniques for assessing the resulting contribution toward actual conservation goals are more challenging to implement [35]. Knowledge of conservation threats is not a guarantee of conservation action [115], and outreach strategies would benefit from pre- and post-evaluations of participants to adapt and improve methodologies. Surveys are one way to assess changes in local knowledge and attitudes to gauge the impact of implementing education and outreach efforts [4]. 
Efforts that move beyond general environmental outreach focus more specifically on ways to change behavior for conservation. For example, the organization Rare draws on the principles of social marketing to develop targeted "pride campaigns" aimed at changing behavior to achieve specific conservation goals, such as protecting a species, habitat, or resource. These campaigns may include 15-20 different in-person and media elements, such as puppet shows, billboards, posters, radio announcements, songs, and video programs [116]. The campaigns seek to change knowledge and attitudes about a particular species or habitat, and campaigns are branded with a charismatic local "flagship species" to help build pride in local diversity. Such campaigns also recognize that knowledge is typically insufficient to change behavior on its own, and therefore seek to create an emotional connection by generating pride, such as with the use of charismatic mascots of local species. This approach includes identifying barriers that may prevent people from changing a particular behavior [117].

Rare takes an adaptive management approach to monitor and evaluate the success of campaigns [116]. Key components are articulating a Theory of Change that begins with knowledge and ends with a conservation result, along with specific objectives and measurable indicators for each target audience. Data about audience knowledge, attitudes, or behaviors are collected before, during, and after campaigns to evaluate these indicators. Other indicators may monitor exposure to various media components of a campaign, perceptions of campaign messages, participation in campaign events, and independent media reports about a campaign [117]. Different communication approaches may be needed at each stage of behavior change, and people may need to receive messages through multiple channels, which provides support for a diverse communication strategy [2,118].

To date, most of the WOM communications have focused on improving knowledge of the Mekong ecosystem. Impact has been measured in terms of the overall reach of media products, and participation in project events. More recent efforts have focused on communicating about specific actions, such as illegal fishing with electrical devices or throwing trash in the river. There exists great opportunity for the project to focus on communication strategies to promote specific actions among audience groups of interest, such as making pledges, participating in river cleanups, or finding ways to promote and share pride in Cambodia's unique natural heritage. Additionally, targeted surveys of WOM audience members could be employed to evaluate perceptions and attitudes about environmental topics. Another important element of environmental education is skill and capacity building and enabling sustainable actions [5,32,37]. To that end, WOM is also developing a series of training courses related to conservation research and communication skills.

Through their engagement with online stories and participation in WOM events, Cambodians have demonstrated great interest in learning about the country's biodiversity. Profiles of fish species were particularly popular, as these types of stories are not found in other media sources in the country. People who do not live near the Mekong environment are unlikely to have encountered many of the river's fish species firsthand; therefore, these stories are a valuable means of raising awareness about aquatic biodiversity. Taking a diverse approach to communication has helped WOM celebrate Cambodia's unique natural wonder, and foster pride in local role models and local stories. A bilingual Facebook page and thoughtful content have been effective for engaging a broad audience, while tangible products such as a fish coloring book have helped facilitate in-person interactions, particularly in rural areas. A cross-cutting initiative to amplify the stories of local conservationists using multiple forms of media has been particularly well received. Future opportunities may include monitoring and measurement of the impact of outreach strategies to better understand shifts in attitudes and behaviors. Increased and improved communication is acutely needed to advance the conservation of freshwater fishes and their habitats [36], and this review covers several communication tools adopted by WOM in the Lower Mekong Basin that may assist other conservation organizations. 
Author Contributions: Conceptualization, E.K.L. and Z.S.H.; writing-literature review and synthesis, J.C.E., E.K.L., and E.G.R.; writing—case study examples, E.K.L., L.S., C.C., S.K., S.L., S.C., D.T., and Z.S.H.; writing-review and editing, E.K.L.; project administration, Z.S.H.; funding acquisition, Z.S.H. All authors have read and agreed to the published version of the manuscript.

Funding: This work was funded through the USAID's 'Wonders of the Mekong' Cooperative Agreement No: AID-OAA-A-16-00057.

Institutional Review Board Statement: Not applicable.

Informed Consent Statement: Not applicable.

Data Availability Statement: Restrictions apply to the availability of these data. Data were obtained from National Geographic, Thmey Thmey, and Facebook, and are available from the authors with the permission of National Geographic, Thmey Thmey, and Wonders of the Mekong.

Conflicts of Interest: The authors declare no conflict of interest.

\section{References}

1. Reddy, S.M.W.; Montambault, J.; Masuda, Y.J.; Keenan, E.; Butler, W.; Fisher, J.R.B.; Asah, S.T.; Gneezy, A. Advancing Conservation by Understanding and Influencing Human Behavior. Conserv. Lett. 2017, 10, 248-256. [CrossRef]

2. Anderson-Wilk, M. Changing the engines of change: Natural resource conservation in the era of social media. J. Soil Water Conserv. 2009, 64, 129A-131A. [CrossRef]

3. Jacobson, S.K.; McDuff, M.D.; Monroe, M.C. Conservation Education and Outreach Techniques; Oxford University Press: Oxford, UK, 2006; p. 496. [CrossRef]

4. $\quad$ Leisher, C.; Mangubhai, S.; Hess, S.; Widodo, H.; Soekirman, T.; Tjoe, S.; Wawiyai, S.; Neil Larsen, S.; Rumetna, L.; Halim, A.; et al. Measuring the benefits and costs of community education and outreach in marine protected areas. Mar. Policy 2012, 36, 1005-1011. [CrossRef]

5. Fien, J. Exploring Principles of Good Practice: Learning from a Meta-Analysis of Case Studies on Education Within Conservation Across the WWF Network. Appl. Environ. Educ. Commun. 2002, 1, 153-162. [CrossRef]

6. Loury, E. Establishing and Managing Freshwater Fish Conservation Zones with Communities: A Guide Based on Lessons Learned from Critical Ecossytem Partnership Fund grantees in the Indo-Burma Hotspot; Critical Ecosystem Partnership Fund: Arlington, VA, USA, 2020.

7. Fabres, B. Think Global, Act Global in the Mekong Delta? Environmental Change, Civil Society, and NGOs. In Environmental Change and Agricultural Sustainability in the Mekong Delta; Stewart, M.A., Coclanis, P.A., Eds.; Springer: Dordrecht, The Netherlands, 2011; pp. 7-34. [CrossRef]

8. Soukhaphon, A.; Baird, I.G.; Hogan, Z.S. The Impacts of Hydropower Dams in the Mekong River Basin: A Review. Water 2021, 13. [CrossRef]

9. Kingston, D.G.; Thompson, J.R.; Kite, G. Uncertainty in Climate Change Projections of Discharge for the Mekong River Basin. Hydrol. Earth Syst. Sci. 2011, 15, 1459-1471. [CrossRef]

10. Kano, Y.; Dudgeon, D.; Nam, S.; Samejima, H.; Watanabe, K.; Grudpan, C.; Grudpan, J.; Magtoon, W.; Musikasinthorn, P.; Nguyen, P.T.; et al. Impacts of Dams and Global Warming on Fish Biodiversity in the Indo-Burma Hotspot. PLoS ONE 2016, 11, e0160151. [CrossRef] [PubMed]

11. Sneddon, C.; Fox, C. Inland Capture Fisheries and Large River Systems: A Political Economy of Mekong Fisheries. J. Agrar. Chang. 2012, 12, 279-299. [CrossRef]

12. Arias, M.E.; Holtgrieve, G.W.; Ngor, P.B.; Dang, T.D.; Piman, T. Maintaining perspective of ongoing environmental change in the Mekong floodplains. Curr. Opin. Environ. Sustain. 2019, 37, 1-7. [CrossRef]

13. Ziv, G.; Baran, E.; Nam, S.; Rodriguez-Iturbe, I.; Levin, S.A. Trading-Off Fish Biodiversity, Food Security, and Hydropower in the Mekong River Basin. Proc. Natl. Acad. Sci. USA 2012, 109, 5609-5614. [CrossRef]

14. Campbell, I.; Barlow, C. Hydropower Development and the Loss of Fisheries in the Mekong River Basin. Front. Environ. Sci. 2020, 8. [CrossRef]

15. Null, S.E.; Farshid, A.; Goodrum, G.; Gray, C.A.; Lohani, S.; Morrisett, C.N.; Prudencio, L.; Sor, R. A Meta-Analysis of Environmental Tradeoffs of Hydropower Dams in the Sekong, Sesan, and Srepok (3S) Rivers of the Lower Mekong Basin. Water 2020, 13. [CrossRef]

16. Intralawan, A.; Wood, D.; Frankel, R.; Costanza, R.; Kubiszewski, I. Tradeoff analysis between electricity generation and ecosystem services in the Lower Mekong Basin. Ecosys. Serv. 2018, 30, 27-35. [CrossRef]

17. Hortle, K.G. Consumption and the Yield of Fish and Other Aquatic Animals from the Lower Mekong Basin; Mekong River Commission: Vientiane, Laos, 2007; p. 87.

18. Food and Agriculture Organization. The State of World Fisheries and Aquaculture 2020. Sustainability in Action; FAO: Rome, Italy, 2020; 206p, ISBN 978-92-5-132692-3. 
19. Riggs, R.A.; Langston, J.D.; Beauchamp, E.; Travers, H.; Ken, S.; Margules, C. Examining Trajectories of Change for Prosperous Forest Landscapes in Cambodia. Environ. Manag. 2020, 66, 72-90. [CrossRef]

20. Ngor, P.B.; McCann, K.S.; Grenouillet, G.; So, N.; McMeans, B.C.; Fraser, E.; Lek, S. Evidence of indiscriminate fishing effects in one of the world's largest inland fisheries. Sci. Rep. 2018, 8, 8947. [CrossRef]

21. Loucks, C.; Mascia, M.B.; Maxwell, A.; Huy, K.; Duong, K.; Chea, N.; Long, B.; Cox, N.; Seng, T. Wildlife decline in Cambodia, 1953-2005: Exploring the legacy of armed conflict. Conserv. Lett. 2009, 2, 82-92. [CrossRef]

22. Campbell, T.; Pin, K.; Ngor, P.; Hogan, Z. Conserving Mekong Megafishes: Current Status and Critical Threats in Cambodia. Water 2020, 12. [CrossRef]

23. Lohani, S.; Dilts, T.; Weisberg, P.; Null, S.; Hogan, Z. Rapidly Accelerating Deforestation in Cambodia's Mekong River Basin: A Comparative Analysis of Spatial Patterns and Drivers. Water 2020, 12. [CrossRef]

24. Thompson, L.C.; Tate, K.W.; Sado, Y.; Forero, L.C. Impact of environmental factors on fish distribution assessed in rangeland streams. Calif. Agric. 2006, 60, 200-206. [CrossRef]

25. Smith, J.; Bunthan, K. Cambodia's Environmental Education Status Report 2005; Live and Learn Environmental Education: Phnom Penh, Cambodia, 2006; p. 56.

26. The World Bank. Literacy Rate, Adult Total (\% of People Ages 15 and Above) - Cambodia. Statistics; The World Bank: Washington, DC, USA, 2015.

27. The World Bank. Rural Population (\% of Total Population) - Cambodia. Revision; The World Bank: Washington, DC, USA, 2019.

28. The World Bank. Population Ages 15-64, Total - Cambodia. Revision; The World Bank: Washington, DC, USA, 2019.

29. Ang, C. Cambodia's 2019 Social Media \& Digital Statistics. Available online: http://geeksincambodia.com/cambodias-2019 -social-media-digital-statistics/ (accessed on 22 October 2020).

30. Ham, S.H.; Krumpe, E.E. Identifying audiences and messages for nonformal environmental education-A theoretical framework for interpreters. J. Interpret. Res. 1996, 1, 13. [CrossRef]

31. Morris, L.; Wilson, S.; Kelly, W. Methods of conducting effective outreach to private well owners-A literature review and model approach. J. Water Health 2016, 14, 167-182. [CrossRef]

32. Monroe, M.C.; Andrews, E.; Biedenweg, K. A Framework for Environmental Education Strategies. Appl. Environ. Educ. Commun. 2008, 6, 205-216. [CrossRef]

33. Kuehne, L.M.; Twardochleb, L.A.; Fritschie, K.J.; Mims, M.C.; Lawrence, D.J.; Gibson, P.P.; Stewart-Koster, B.; Olden, J.D. Practical science communication strategies for graduate students. Conserv. Biol. 2014, 28, 1225-1235. [CrossRef] [PubMed]

34. McKenzie-Mohr, D.; Schultz, P.W. Choosing Effective Behavior Change Tools. Soc. Mark. Q. 2014, 20, 35-46. [CrossRef]

35. Twardek, W.M.; Wanningen, H.; Fernández Garrido, P.; Brink, K.; Royte, J.; Berkhuysen, A.; Geenen, B.; Cooke, S.J. World Fish Migration Day Connects Fish, Rivers, and People - From a One-Day Event to a Broader Social Movement. Fisheries 2020, 45, 465-474. [CrossRef]

36. Cooke, S.J.; Lapointe, N.W.R.; Martins, E.G.; Thiem, J.D.; Raby, G.D.; Taylor, M.K.; Beard, T.D.; Cowx, I.G. Failure to engage the public in issues related to inland fishes and fisheries: Strategies for building public and political will to promote meaningful conservation. J. Fish Biol. 2013, 83, 997-1018. [CrossRef] [PubMed]

37. Fien, J.; Scott, W.; Tilbury, D. Education and Conservation: Lessons from an evaluation. Environ. Educ. Res. 2001, 7, 379-395. [CrossRef]

38. Haywood, B.K.; Besley, J.C. Education, outreach, and inclusive engagement: Towards integrated indicators of successful program outcomes in participatory science. Public. Underst. Sci. 2014, 23, 92-106. [CrossRef]

39. Salmon, R.A.; Priestley, R.K.; Goven, J. The reflexive scientist: An approach to transforming public engagement. J. Environ. Stud. Sci. 2015, 7, 53-68. [CrossRef]

40. Chan, B.; Sor, R.; Ngor, P.B.; Baehr, C.; Lek, S. Modelling spatial and temporal dynamics of two small mud carp species in the Tonle Sap flood-pulse ecosystem. Ecolog. Model. 2019, 392, 82-91. [CrossRef]

41. Chan, B.; Brosse, S.; Hogan, Z.; Ngor, P.; Lek, S. Influence of Local Habitat and Climatic Factors on the Distribution of Fish Species in the Tonle Sap Lake. Water 2020, 12. [CrossRef]

42. McElroy, M.E.; Dressler, T.L.; Titcomb, G.C.; Wilson, E.A.; Deiner, K.; Dudley, T.L.; Eliason, E.J.; Evans, N.T.; Gaines, S.D.; Lafferty, K.D.; et al. Calibrating Environmental DNA Metabarcoding to Conventional Surveys for Measuring Fish Species Richness. Front. Ecolog. Evolut. 2020, 8. [CrossRef]

43. Pin, K.; Nut, S.; Hogan, Z.S.; Chandra, S.; Saray, S.; Touch, B.; Chheng, P.; Ngor, P.B. Cambodian Freshwater Fish Assemblage Structure and Distribution Patterns: Using a Large-Scale Monitoring Network to Understand the Dynamics and Management Implications of Species Clusters in a Global Biodiversity Hotspot. Water 2020, 12. [CrossRef]

44. Ballantyne, R.; Connell, S.; Fien, J. Students as Catalysts of Environmental Change: A framework for researching intergenerational influence through environmental education. Environ. Educ. Res. 1998, 4, 285-298. [CrossRef]

45. Hollweg, K.S.; Taylor, J.R.; Bybee, R.W.; Marcinkowski, T.J.; McBeth, W.C.; Zoido, P. Developing a Framework for Assessing Environmental Literacy; North American Association for Environmental Education: Washington, DC, USA, 2011.

46. Ramsey, J.M.; Hungerford, H.R.; Volk, T.L. Environmental Education in the K-12 Curriculum: Finding a Niche. J. Environ. Educ. 1992, 23, 35-45. [CrossRef]

47. Stanišić, J.; Maksić, S. Environmental Education in Serbian Primary Schools: Challenges and Changes in Curriculum, Pedagogy, and Teacher Training. J. Environ. Educ. 2014, 45, 118-131. [CrossRef] 
48. Alò, D.; Castillo, A.; Marín Vial, P.; Samaniego, H. Low-cost emerging technologies as a tool to support informal environmental education in children from vulnerable public schools of southern Chile. Internat. J. Sci. Educ. 2020, 42, 635-655. [CrossRef]

49. Kudryavtsev, A.; Krasny, M.E.; Stedman, R.C. The impact of environmental education on sense of place among urban youth. Ecosphere 2012, 3. [CrossRef]

50. Farmer, J.; Knapp, D.; Benton, G.M. An Elementary School Environmental Education Field Trip: Long-Term Effects on Ecological and Environmental Knowledge and Attitude Development. J. Environ. Educ. 2007, 38, 33-42. [CrossRef]

51. Behrendt, M.; Franklin, T. A Review of Research on School Field Trips and Their Value in Education. Internat. J. Environ. Sci. Educ. 2014, 9, 11. [CrossRef]

52. Dori, Y.J.; Tal, R.T. Formal and Informal Collaborative Projects: Engaging in Industry with Environmental Awareness. Sci. Educ. 2000, 84, 19. [CrossRef]

53. Zint, M.; Kraemer, A.; Kolenic, G. Evaluating Meaningful Watershed Educational Experiences: An exploration into the effects on participating students' environmental stewardship characteristics and the relationships between these predictors of environmentally responsible behavior. Stud. Educ. Evaluat. 2014, 41, 4-17. [CrossRef]

54. Bourassa, L. The Ripple Effect: Youth Leadership Development and Influence on Environmental Engagement in the Community; Wilfrid Laurier University: Waterloo, ON, Canada, 2017.

55. Mustam, B.; Daniel, E.S. Informal And Formal Environmental Education Infusion: Actions of Malaysian Teachers and Parents Among Students in a Polluted Area. Malaysian Online J. Educ. Sci. 2018, 4, 12.

56. Činčera, J.; Romero-Ariza, M.; Zabic, M.; Kalaitzidaki, M.; del Consuelo Díez Bedmar, M. Environmental Citizenship in Primary Formal Education. In Conceptualizing Environmental Citizenship for 21st Century Education; Cooper, C., Espinet, M., Greenwood, D., McKinley, E., Pierce, C., Rivera Manlucci, M.S., Reis, G., Eds.; Springer: Cham, Switzerland, 2020; Volume 4, pp. 163-178.

57. Department of Curriculum Development. Curriculum Framework of General Education and Technical Education; Ministry of Education, Youth and Sport: Phnom Penh, Cambodia, 2015.

58. Ministry of Environment; Ministry of Education. Guidebook on Climate Change for Primary and Secondary Level; Ministry of Education, Youth and Sport: Phnom Penh, Cambodia, 2019; p. 67.

59. Chea, P.; Dearing, C. Teacher's Guidebook: The Teaching of "A History of Democratic Kampuchea (1975-1979)"; Documentation Center of Cambodia and the Ministry of Education, Youth and Sport: Phnom Penh, Cambodia, 2009.

60. Stern, M.J. Coercion, voluntary compliance and protest: The role of trust and legitimacy in combating local opposition to protected areas. Environ. Conserv. 2008, 35, 200-210. [CrossRef]

61. Hill, N.S.; Bartol, K.M.; Tesluk, P.E.; Langa, G.A. Organizational context and face-to-face interaction: Influences on the development of trust and collaborative behaviors in computer-mediated groups. Organ. Behav. Hum. Decis. Process 2009, 108, 187-201. [CrossRef]

62. MacKeracher, T.; Diedrich, A.; Gurney, G.G.; Marshall, N. Who trusts whom in the Great Barrier Reef? Exploring trust and communication in natural resource management. Environ. Sci. Pol. 2018, 88, 24-31. [CrossRef]

63. Nisbet, M.C.; Scheufele, D.A. What's next for science communication? Promising directions and lingering distractions. Am. J. Bot 2009, 96, 1767-1778. [CrossRef] [PubMed]

64. Pinker, S. The Village Effect: How Face-to-Face Contact Can Make Us Healthier and Happier; Spiegel \& Grau: New York, NY, USA, 2015; p. 432.

65. Sayer, E.J.; Featherstone, H.C.; Gosling, W.D.; Roadies, B.E.S. Sex \& Bugs \& Rock 'n Roll—Getting creative about public engagement. Trends Ecol. Evol. 2014, 29, 65-67. [CrossRef] [PubMed]

66. Klionsky, D.J. Autophagy: Research topic, painting, poem, dance...: The combination of art and information can enhance the enjoyment and effectiveness of learning. EMBO Rep. 2015, 16, 547-552. [CrossRef]

67. Olmedo, A.; Milner-Gulland, E.J.; Challender, D.W.S.; Cugnière, L.; Dao, H.T.T.; Nguyen, L.B.; Nuno, A.; Potier, E.; Ribadeneira, M.; Thomas-Walters, L.; et al. A scoping review of celebrity endorsement in environmental campaigns and evidence for its effectiveness. Conserv. Sci. Pract. 2020, 2. [CrossRef]

68. Ferderbar, C.A. The Effects of In-Nature and Virtual-Nature Field Trip Experiences on Proenvironmental Attitudes, Behaviors, and Environmental Knowledge of Middle School Students. Ph.D. Thesis, Cardinal Stritch University, Milwaukee, WI, USA, 2013.

69. Chawla, L.; Cushing, D.F. Education for strategic environmental behavior. Environ. Educ. Res. 2007, 13, 437-452. [CrossRef]

70. Wells, N.M.; Lekies, K.S. Nature and the life course: Pathways from childhood nature experiences to adult environmentalism. Child. Youth Environ. 2006, 16, 24.

71. Hofstein, A.; Rosenfeld, S. Bridging the Gap Between Formal and Informal Science Learning. Stud. Sci. Educ. 1996, 28, 87-112. [CrossRef]

72. Knapp, D.; Barrie, E. Content evaluation of an environmental science field trip. J. Sci. Educ. Technol. 2001, 10, 7. [CrossRef]

73. Falk, J.H.; Dierking, L.D. School field trips: Assessing their long-term impact. Curator Museum J. 1997, 40, 8. [CrossRef]

74. Dietz, J.M.; Aviram, R.; Bickford, S.; Douthwaite, K.; Goodstine, A.; Izursa, J.-L.; Kavanaugh, S.; MacCarthy, K.; O’Herron, M.; Parker, K. Defining Leadership in Conservation: A View from the Top. Conserv. Biol. 2004, 18, 274-278. [CrossRef]

75. Czippan, K.; Charles, C.; Abd-Alhadi, F.; Abdallah, A.; Zavarazin, A.; Pisupati, B.; Sziva, D.; Li, H.; Camargo, L.; Ratiani, M.; et al. Visions and Recommendations for the Futures of Education By the IUCN Commission on Education and Communication (CEC); IUCN: Grand, Switzerland, 2021; p. 18. 
76. Sander, B. The importance of education in ecotourism ventures: Lessons from Rara Avis ecolodge, Costa Rica. Internat. J. Sustain. Soc. 2012, 4, 16. [CrossRef]

77. Jacobson, S.K.; Robles, R. Ecotourism, sustainable development, and conservation education: Development of a tour guide training program in Tortuguero, Costa Rica. Environ. Manag. 1992, 16, 13. [CrossRef]

78. Tuthill, G.; Klemm, E.B. Virtual field trips: Alternatives to actual field trips. Internat. J. Instruct. Media 2002, $29,16$.

79. Klemm, E.B.; Tuthill, G. Virtual field trips: Best practices. Internat. J. Instruct. Media 2003, 30, 17.

80. Stoddard, J. Toward a virtual field trip model for the social studies. Contemp. Issues Technol. Teach. Educ. $2009,9,27$.

81. Clark, K.F.; Hosticka, A.; Schriver, M.; Bedell, J. Computer based virtual field trips. In Proceedings of the ED-MEDIA 2002 World Conference on Educational Multimedia, Hypermedia, and Telecommunications, Denver, CO, USA, 24-29 June 2002 ; p. 6.

82. Colleton, N.; Lakshman, V.; Flood, K.; Birnbaum, M.; McMillan, K.; Lin, A. Concepts and practice in the emerging use of games for marine education and conservation. Aquat. Conserv. Mar. Freshw. Ecosyst. 2016, 26, 213-224. [CrossRef]

83. McCabe, S.; Nekaris, K.A.I. The impact of subtle anthropomorphism on gender differences in learning conservation ecology in Indonesian school children. Appl. Environ. Educ. Commun. 2018, 18, 13-24. [CrossRef]

84. Forrest, C.J. Environmental public involvement and outreach: Tools and commentary. Environ. Qual. Manag. 2012, 22, 1-19. [CrossRef]

85. Wright, A.J.; Veríssimo, D.; Pilfold, K.; Parsons, E.C.M.; Ventre, K.; Cousins, J.; Jefferson, R.; Koldewey, H.; Llewellyn, F.; McKinley, E. Competitive outreach in the 21st century: Why we need conservation marketing. Ocean Coast. Manag. 2015, 115, 41-48. [CrossRef]

86. Talero, G. Environmental Education and Public Awareness; WorldFish: Victoria, BC, Canada, 2004.

87. Roberge, J.-M. Using data from online social networks in conservation science: Which species engage people the most on Twitter? Biodivers. Conserv. 2014, 23, 715-726. [CrossRef]

88. Cooke, S.J.; Gallagher, A.J.; Sopinka, N.M.; Nguyen, V.M.; Skubel, R.A.; Hammerschlag, N.; Boon, S.; Young, N.; Danylchuk, A.J.; Metcalf, V. Considerations for effective science communication. Facets 2017, 2, 233-248. [CrossRef]

89. Spicer, S. Exploring Video Abstracts in Science Journals: An Overview and Case Study. J. Libr. Sch. Commun. 2014, 2. [CrossRef]

90. Bortree, D.S.; Seltzer, T. Dialogic strategies and outcomes: An analysis of environmental advocacy groups' Facebook profiles. Public Relat. Rev. 2009, 35, 317-319. [CrossRef]

91. Monroe, J.B.; Baxter, C.V.; Olden, J.D.; Angermeier, P.L. Freshwaters in the Public Eye: Understanding the Role of Images and Media in Aquatic Conservation. Fisheries 2009, 34, 581-585. [CrossRef]

92. Staaterman, E.; Bhandiwad, A.; Gravinese, P.; Moeller, P.; Reichenbach, Z.; Shantz, A.; Shiffman, D.; Toth, L.; Warneke, A.; Gallagher, A. Lights, camera, science: The utility and growing popularity of film festivals at scientific meetings. Ideas Ecol. Evol. 2014, 7. [CrossRef]

93. Papworth, S.K.; Nghiem, T.P.; Chimalakonda, D.; Posa, M.R.; Wijedasa, L.S.; Bickford, D.; Carrasco, L.R. Quantifying the role of online news in linking conservation research to Facebook and Twitter. Conserv. Biol. 2015, 29, 825-833. [CrossRef]

94. Nghiem, L.T.; Webb, E.L.; Carrasco, L.R. Saving Vietnam's wildlife through social media. Science 2012, 338, 192-193. [CrossRef]

95. Aravind, N.A. Potential of social network and internet media for biodiversity mapping and conservation. Curr. Sci. 2013, 105, 3 .

96. Shiffman, D.S. Twitter as a tool for conservation education and outreach: What scientific conferences can do to promote live-tweeting. J. Environ. Stud. Sci. 2012, 2, 257-262. [CrossRef]

97. Barry, S.J. Using social media to discover public values, interests, and perceptions about cattle grazing on park lands. Environ. Manag. 2014, 53, 454-464. [CrossRef]

98. Toivonen, T.; Heikinheimo, V.; Fink, C.; Hausmann, A.; Hiippala, T.; Järv, O.; Tenkanen, H.; Di Minin, E. Social media data for conservation science: A methodological overview. Biolog. Conserv. 2019, 233, 298-315. [CrossRef]

99. Sullivan, M.; Robinson, S.; Littnan, C. Social media as a data resource for \#monkseal conservation. PLoS ONE 2019, 14, e0222627. [CrossRef]

100. Levin, N.; Kark, S.; Crandall, D. Where have all the people gone? Enhancing global conservation using night lights and social media. Ecolog. Applicat. 2015, 25, 15. [CrossRef]

101. Wood, S.A.; Guerry, A.D.; Silver, J.M.; Lacayo, M. Using social media to quantify nature-based tourism and recreation. Sci. Rep. 2013, 3, 2976. [CrossRef]

102. Di Minin, E.; Tenkanen, H.; Toivonen, T. Prospects and challenges for social media data in conservation science. Front. Environ. Sci. 2015, 3. [CrossRef]

103. Jaric, I.; Roll, U.; Arlinghaus, R.; Belmaker, J.; Chen, Y.; China, V.; Douda, K.; Essl, F.; Jahnig, S.C.; Jeschke, J.M.; et al. Expanding conservation culturomics and iEcology from terrestrial to aquatic realms. PLoS Biol. 2020, 18, e3000935. [CrossRef]

104. Hausmann, A.; Toivonen, T.; Slotow, R.; Tenkanen, H.; Moilanen, A.; Heikinheimo, V.; Di Minin, E. Social Media Data Can Be Used to Understand Tourists' Preferences for Nature-Based Experiences in Protected Areas. Conserv. Lett. 2018, 11. [CrossRef]

105. Abuthagir, I.S.; Rathinam, B.; Pradhan, S.; Kumar, J. Facebook Fisheries: A tool towards inmprovment of fisheries and fishers. Fish. Chimes 2018, 38, 3.

106. Heikinheimo, V.; Minin, E.D.; Tenkanen, H.; Hausmann, A.; Erkkonen, J.; Toivonen, T. User-Generated Geographic Information for Visitor Monitoring in a National Park: A Comparison of Social Media Data and Visitor Survey. ISPRS Int. J. Geo Inf. 2017, 6. [CrossRef] 
107. Latzke, K.; Marker, L.; Ravenscroft, H. Engaging a global Facebook audience with conservation education. J. Environ. Stud. Sci. 2019, 9, 437-441. [CrossRef]

108. Taylor, A.T.; Sammons, S.M. Bridging the Gap between Scientists and Anglers: The Black Bass Conservation Committee's Social Media Outreach Efforts. Fisheries 2019, 44, 37-41. [CrossRef]

109. Kidd, L.R.; Gregg, E.A.; Bekessy, S.A.; Robinson, J.A.; Garrard, G.E. Tweeting for their lives: Visibility of threatened species on twitter. J. Nat. Conserv. 2018, 46, 106-109. [CrossRef]

110. Wu, Y.; Xie, L.; Huang, S.-L.; Li, P.; Yuan, Z.; Liu, W. Using social media to strengthen public awareness of wildlife conservation. Ocean. Coast. Manag. 2018, 153, 76-83. [CrossRef]

111. De Vos, A. The Problem of 'Colonial Science'. In Scientific American; Springer Nature: London, UK, 2020.

112. Elliott, L.; Ryan, M.; Wyborn, C. Global patterns in conservation capacity development. Biolog. Conserv. 2018, 221, 261-269. [CrossRef]

113. Sor, R.; Ngor, P.B.; Soum, S.; Chandra, S.; Hogan, Z.S.; Null, S.E. Water Quality Degradation in the Lower Mekong Basin. Water 2021, 13, 1555. [CrossRef]

114. Schultz, P.W. Conservation means behavior. Conserv. Biol. 2011, 25, 1080-1083. [CrossRef] [PubMed]

115. Kollmuss, A.; Agyeman, J. Mind the Gap: Why do people act environmentally and what are the barriers to pro-environmental behavior? Environ. Educ. Res. 2010, 8, 239-260. [CrossRef]

116. Jenks, B.; Vaughan, P.W.; Butler, P.J. The evolution of Rare Pride: Using evaluation to drive adaptive management in a biodiversity conservation organization. Eval. Program. Plann. 2010, 33, 186-190. [CrossRef] [PubMed]

117. Butler, P.; Green, K.; Galvin, D. The Principles of Pride: The Science Behind the Mascots; Rare: Arlington, VA, USA, 2013.

118. Israel, G.D.; Wilson, K.M. Sources and Channels of Information Used by Educational Program Clients. J. App. Commun. 2006, 90. [CrossRef] 